U.S. DEPARTMENT OF COMMERCE

National Institute of Standards and Technology

NIST BUILDING SCIENCE SERIES 167

\title{
Interim Criteria for Polymer-Modified Bituminous Roofing Membrane Materials
}

Walter J. Rossiter, Jr.

James F. Seiler, Jr.

TA

435

.458

No. 167

1989

c. 2 
NATIONAL INSTITUTE OF STANDARDS TECHNOLOGY

Research Information Center

Gaithersburg, MD 20899 


\section{NIST BUILDING SCIENCE SERIES 167}

\section{Interim Criteria for Polymer-Modified Bituminous Roofing Membrane Materials}

Walter J. Rossiter, Jr.

James F. Seiler, Jr.

Building Materials Division

Center for Building Technology

National Institute of Standards and Technology

Gaithersburg, MD 20899

Prepared for:

Tri-Service Building Materials Committee

Headquarters, U.S. Army Corps of Engineers

Washington, DC 20314-1000

U.S. Navy, Naval Facilities Engineering Command

Alexandria, VA 22332-2300

Headquarters, U.S. Air Force, Engineering Division

Bolling Air Force Base, DC 20332-5000

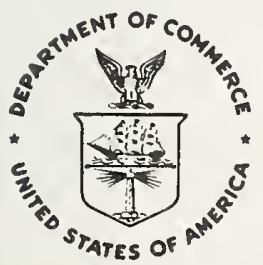

NOTE: As of 23 August 1988, the National Bureau of Standards (NBS) became the National Institute of Standards and Technology (NIST) when President Reagan signed into law the Omnibus Trade and Competitiveness Act.

Issued February 1989

U.S. DEPARTMENT OF COMMERCE, Robert A. Mosbacher, Secretary Ernest Ambler, Acting Under Secretary for Technology NATIONAL INSTITUTE OF STANDARDS AND TECHNOLOGY Raymond G. Kammer, Acting Director 
Library of Congress Catalog Card Number: 89-600702

National Institute of Standards and Technology Building Science Series 167 Natl. Inst. Stand. Technol. Bldg. Sci. Ser. 167, 50 pages (Feb. 1989)

CODEN: NBSSES 


\begin{abstract}
This report presents the results of a study to develop interim criteria for the selection of polymer-modified bituminous roofing membrane materials. The criteria are based on a review of existing standard specifications and related documents. They are intended for use by the construction agencies of the Department of Defense in specifying polymer-modified bituminous roofing membrane materials until voluntary consensus standards are developed in the United States.

The suggested interim criteria are generally presented using a performance criteria format. The membrane characteristics for which performance criteria are suggested are: dimensional stability, fire, flow resistance, hail impact, moisture content and absorption, pliability, strain energy, uplift resistance, and weathering resistance (heat exposure). Prescriptive criteria for five membrane characteristics are used to complement the suggested performance criteria. The approach of using complementary prescriptive criteria is taken to incorporate in the performance criteria tests methods which can be relatively rapidly performed for characterization or identification of the membrane material.

Other membrane requirements are listed for future development of criteria, but performance criteria for these requirements are not suggested at the present. Lack of a consistent database in the existing standards and related documents precludes suggesting criteria at this time. It is considered beneficial to present the needed criteria as a first step toward directing future research for standards development for polymer-modified bituminous roofing membrane materials.
\end{abstract}

Key words: characteristics; membranes; low-sloped roofing; performance criteria; prescriptive criteria; polymer-modified bitumens; properties; roofs; test methods 


\section{CONTENTS}

page

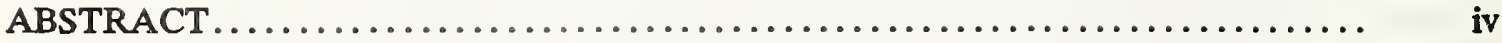

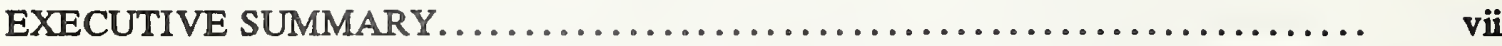

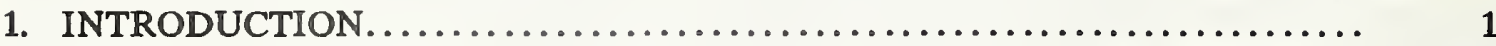

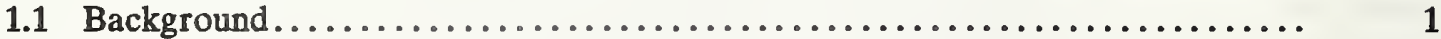

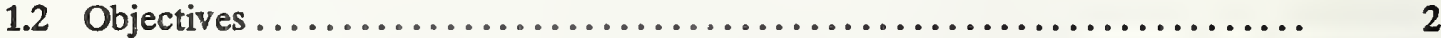

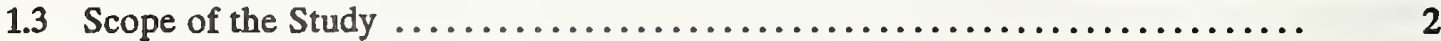

1.4 Performance Specifications................................... 2

1.5 Modifiers and Reinforcements for Modified Bitumens .................. 3

2. STANDARDS AND RELATED DOCUMENTS FOR POLYMER-MODIFIED BITUMINOUS ROOFING MEMBRANE MATERIALS . ....................

3. SUGGESTED INTERIM CRITERIA......................... 5

3.1 Prescriptive Requirements for Characterization...................... 5

3.2 Suggested Interim Performance Criteria .......................... 7

3.3 Needed Criteria for Future Development...................... 11

4. SUMMARY AND CONCLUSIONS............................ 16

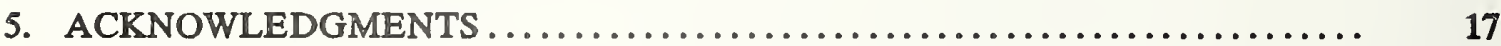

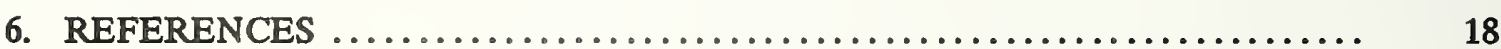

APPENDIX A. PRELIMINARY DATA ON TYPICAL POLYMER-MODIFIED BITUMINOUS ROOFING MEMBRANE MATERIALS ........ A1

APPENDIX B. ASTM DRAFT TEST PROCEDURES CITED IN THE CRITERIA.................................. B1

APPENDIX C. UEATC TEST PROCEDURES CITED IN THE CRITERIA..... . C1 


\section{LIST OF TABLES}

Table 1. Summary of suggested prescriptive criteria for modified bitumens........ viii

Table 2. Summary of suggested performance criteria for modified bitumens

incorporating membrane system tests ...................... viii

Table 3. Summary of suggested performance criteria for modified bitumens incorporating membrane material tests...................... ix

Table 4. Documents containing criteria applicable to bituminous roofing membranes .

Table 5. Summary of requirements given in the documents containing criteria

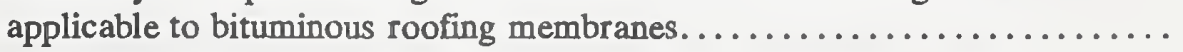

Table 6. Prescriptive requirements for polymer-modified bituminous roofing

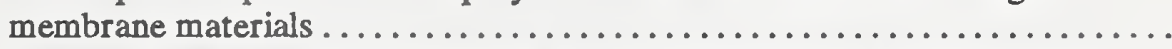

Table 7. Summary of suggested prescriptive and performance criteria for modified

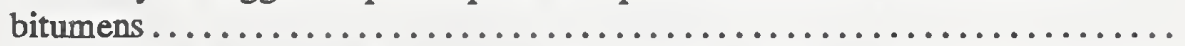

Table 8. Summary of membrane requirements of modified bitumens for which criteria

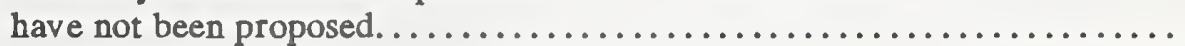

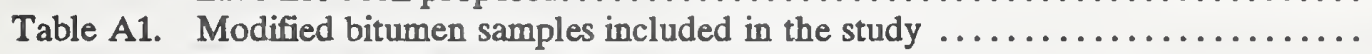

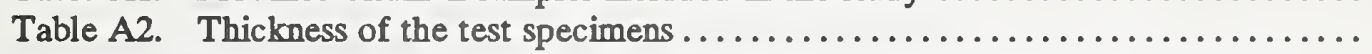

Table A3. Tensile strength of the specimens tested at 73 and $0^{\circ} \mathrm{F}\left(23\right.$ and $\left.-18^{\circ} \mathrm{C}\right)$

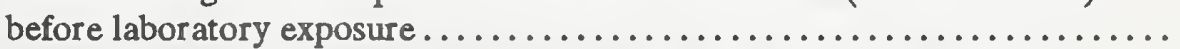

Table A4. Elongation of the specimens under tensile load tested at 73 and $0{ }^{\circ} \mathrm{F}$

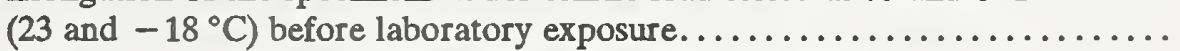

Table A5. Low-temperature flexibility of the test specimens before laboratory

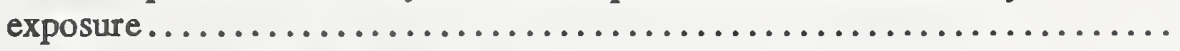

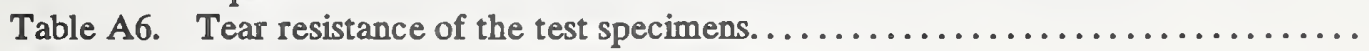

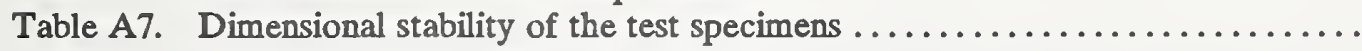

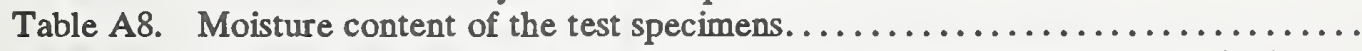

Table A9. Strain energy per unit gage length of the specimens tested at 73 and $0{ }^{\circ} \mathrm{F}$

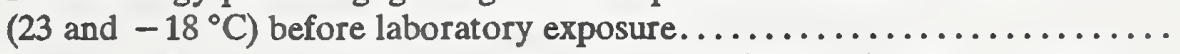

Table A10. Tensile strength of the specimens tested at $0^{\circ} \mathrm{F}\left(-18^{\circ} \mathrm{C}\right)$ after laboratory

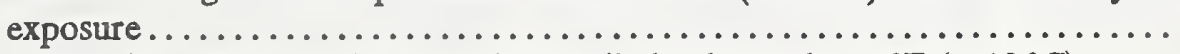

Table A11. Elongation of the specimens under tensile load tested at $0^{\circ} \mathrm{F}\left(-18^{\circ} \mathrm{C}\right)$

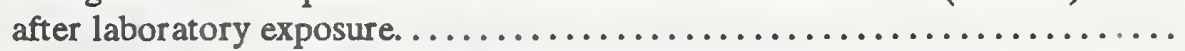

Table A12. Low-temperature flexibility of the test specimens after laboratory exposure. .

Table A13. Strain energy per unit gage length of the specimens tested at $0^{\circ} \mathrm{F}\left(-18^{\circ} \mathrm{C}\right)$

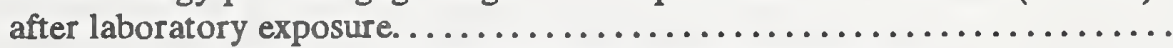

Table A14. Test results of the heat-exposed samples compared with the

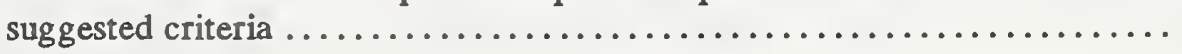

\section{LIST OF FIGURES}

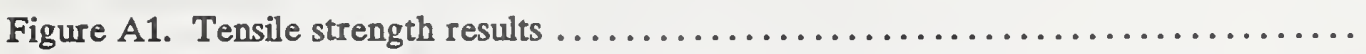

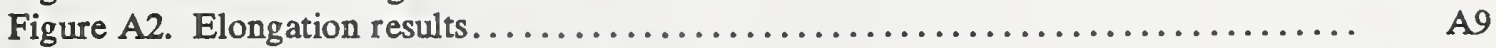

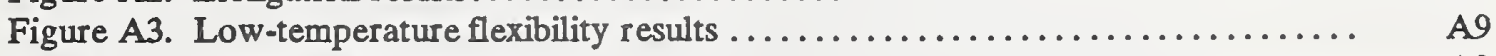

Figure A4. Strain energy results. ................................. A9 



\section{EXECUTIVE SUMMARY}

The use of low-sloped roof membranes fabricated from polymer-modified bituminous materials has been increasing in the United States. From little use a decade ago, U.S. annual installation of modified bitumens is now reported to be about 16 percent of membrane roofing. Some projections indicate that their use by 1990 will be in the range of 27 to 33 percent of the area of membranes installed.

A major problem for the U.S. roofing industry has been the lack of consensus standards and criteria for selection and use of the polymer-modified bituminous roofing membrane materials. Although performance has generally been satisfactory for the limited period of time that they have been available, the rapid growth in use has raised questions concerning long-term performance of materials which may enter the market without adequate evaluation. Although consensus standards and related criteria for selection and use of the modified bitumens are not yet available in the United States, many documents have been developed in North America and Europe which might provide the starting point for the U.S. industry. Also, a draft ASTM standard on methods for sampling and testing modified bitumens has been extensively reviewed by an ASTM Subcommittee and is near to consensus agreement at the Subcommittee level.

The construction agencies of the U.S. Department of Defense (DOD) consider that benefits are to be gained in having available alternative materials for fabricating membranes for low-sloped roofing systems. However, they are reluctant to use the newer membrane materials such as the modified bitumens without having available selection criteria for guide specifications or other construction documents. The development of such criteria through ASTM or other industry organizations is not expected to be complete for many months. Thus, DOD requested that the National Institute of Standards and Technology (NIST) (formerly National Bureau of Standards/NBS) conduct a study to provide interim criteria for use in military guide specifications. This report presents the results of the study.

The objectives of this report are: 1) to provide a listing of documents that pertain to the development of selection criteria for modified bitumens, and to summarize the characteristics evaluated in the documents, 2) to suggest selection criteria that may be used by the DOD construction agencies in the absence of voluntary consensus standards in the United States, and 3) to provide data that may assist in the development of voluntary consensus standards. The scope of the study focused on a review of standards and related documents which could serve as the basis for the development of interim selection criteria.

As a first step in providing data to support the development of the suggested criteria, limited testing was conducted using typical commercially available modified bitumens. Data on the following properties are reported for five unaged membrane materials: thickness, tensile strength, elongation, low-temperature flexibility, tear resistance, dimensional stability, moisture content, and strain energy. In addition, data on tensile strength, elongation, low-temperature flexibility, and strain energy are reported after exposure of the membrane materials to the heat and ultraviolet conditions given in the ASTM draft.

The criteria are divided into two categories: 1) prescriptive criteria concerning the characterization of the material as manufactured, and 2) performance criteria concerning properties associated with in-service behavior. A performance specification defines a product in terms of the functions it is to perform; whereas a prescriptive specification defines a product in terms of its constituents and their relationships to each other. One benefit of prescriptive criteria is that they provide a means to assure that the product reaching the market has the selected property values agreed upon between seller and buyer. Moreover, test methods for prescriptive criteria are often more practical than performance tests for routine product characterization. The criteria suggested herein are primarily in performance criteria format, but are complemented with prescriptive criteria.

In the development of the criteria suggested herein, chief consideration was given to the use of test methods under review by ASTM. This approach was taken in order to promote compatibility between interim criteria suggested in the present report and voluntary consensus requirements likely to be recommended by ASTM Committee D08. 
Table 1 presents the suggested prescriptive requirements associated with the selected tests given in the ASTM draft. The suggestion for these requirements is that the average measured property values of the membrane product, as supplied to the user, should not be less than (or where appropriate, greater than) a given percentage of the nominal values as stated by the manufacturer (perhaps in the product literature or in the NRCA Materials Guide) for the membrane material. This approach is considered more practical for assuring that the material supplied to a DOD agency is that normally produced by the manufacturer, than if the requirement specified a minimum property value. The requirements for thickness, low-temperature flexibility, and tear resistance have included a suggested limiting value for the membrane products.

Table 1. Summary of suggested prescriptive criteria for modified bitumens

\begin{tabular}{lll}
\hline \hline \multicolumn{1}{c}{ Requirement } & \multicolumn{1}{c}{ Test Method } & \multicolumn{1}{c}{ Criterion } \\
\hline Thickness & ASTM draft, Sec. 5 & $\begin{array}{l}\text { not }<5 \% \text { of the nominal value, } 40 \text { mil } \\
(1 \mathrm{~mm}) \text { minimum }\end{array}$ \\
Load, max. & ASTM draft, Sec. 6 & not $<15 \%$ of the nominal value \\
Elongation (max. load) & ASTM draft, Sec. 6 & not $<20 \%$ of the nominal value \\
Elongation (break) & ASTM draft, Sec. 6 & not $<20 \%$ of the nominal value \\
Low-Temperature Flexibility & ASTM draft, Sec. 11 & not $>5^{\circ} \mathrm{F}\left(3^{\circ} \mathrm{C}\right)$ of nominal, $25^{\circ} \mathrm{F}$ \\
& & $\left(-4^{\circ} \mathrm{C}\right)$ maximum \\
Tear Resistance & ASTM draft, Sec. 7 & $(130 \mathrm{~N})$ minimum
\end{tabular}

The suggested performance criteria are presented in the format developed in Building Science Series 55, which suggested preliminary performance criteria for bituminous built-up membrane materials. This format has four key elements: requirement, criterion, test method, and commentary. The membrane and system characteristics for which criteria are suggested are: dimensional stability, fire resistance, flow resistance, hail impact resistance, moisture content and absorption, pliability, strain energy, uplift resistance, and weathering resistance (heat exposure). Some of the performance criteria, notably those on fire, flow, hail, strain energy, and uplift pertain to the modified bitumen as used in the roof system. The criteria incorporating system tests are summarized in table 2 . The remaining criteria are specific to the membrane material alone, and are summarized in table 3 . As a practical consideration, tests of the membrane material alone may be more readily conducted on a routine basis than membrane system tests.

Table 2. Summary of suggested performance criteria for modified bitumens incorporating membrane system tests

\begin{tabular}{|c|c|c|}
\hline Requirement & Test Method & Criterion \\
\hline Fire Resistance & ASTM, UL, or FM test & conform to applicable code \\
\hline Flow Resistance & $\begin{array}{l}\text { UEAtc No. } 27 \\
\text { Sec. } 5.1 .7\end{array}$ & no slippage \\
\hline \multirow[t]{3}{*}{ Hail Impact } & NBS BSS 55 & $\begin{array}{l}1.5 \mathrm{in}(38 \mathrm{~mm}) \text { hail stone at } 112 \mathrm{ft} / \mathrm{s} \\
(34 \mathrm{~m} / \mathrm{s}) \text { without water penetration }\end{array}$ \\
\hline & or & \\
\hline & ASTM D 3746 & $\begin{array}{l}22 \text { lbfft ( } 30 \mathrm{~J} \text { ) without water } \\
\text { penetration }\end{array}$ \\
\hline Strain Energy & ASTM draft, Sec. 6 & not less than $3 \mathrm{lbf} \cdot \mathrm{in} / \mathrm{in}^{2}\left(0.5 \mathrm{kN} \cdot \mathrm{m} / \mathrm{m}^{2}\right)$ \\
\hline Uplift & ASTM, UL, or FM test & conform to applicable code \\
\hline
\end{tabular}


Table 3. Summary of suggested performance criteria for modified bitumens incorporating membrane material tests

\begin{tabular}{lll}
\hline \hline \multicolumn{1}{c}{ Requirement } & \multicolumn{1}{c}{ Test Method } & \multicolumn{1}{c}{ Criterion } \\
\hline $\begin{array}{l}\text { Dimensional Stability } \\
\text { Moisture Absorp. }\end{array}$ & ASTM draft, Sec. 10 & max. change, $\pm 1 \%$ \\
Moisture Content & ASTM draft, Sec. 9 & 1 gram (per specimen), max. \\
Pliability & ASTM draft, Sec. 8 & $0.5 \%$ by mass, max. \\
& a) ASTM draft, Sec. 11 & no cracking at temperatures \\
& & of application
\end{tabular}

The interim criteria suggested in the present report are not complete. When the study was initiated, it was realized that gaps would probably exist in the initial criteria proposed on the basis of a review of existing information. It was thought, at the time, that the available database for the characterization and evaluation of modified bitumens would be insufficient to support a complete set of criteria. The membrane requirements for which criteria are considered to be needed, but were not developed in the present report are: cyclic (substrate) movement resistance, durability of protective surfacings, puncture resistance, seam strength, slippage resistance of base flashings, tear resistance, water transmission resistance, and weather resistance (except heat exposure). Because of the importance of having criteria for these requirements, an initial step in outlining performance criteria using the standard format was undertaken, but the criteria themselves were not proposed. A benefit in presenting this outline of needed criteria is to define the gaps for future criteria development and the needs for research to develop performance data. As future development of the criteria continues, the results should be incorporated in DOD guide specifications. 



\section{INTRODUCTION}

\subsection{Background}

The use of low-sloped roof membranes fabricated from polymer-modified bituminous materials has been increasing in the United States. A polymer-modified bituminous roofing membrane material $^{1}$ has been described as a factory-prefabricated, reinforced sheet, composed basically of bitumen, reinforcement, and various bitumen modifiers [1]. The modifiers are intended to extend the useful temperature range of the bitumen by lowering the brittle point and raising the softening point [2]. A practical advantage of modified bitumens for roof membranes is that, being bituminous, they closely resemble built-up roofing and are compatible with existing built-up roofing construction details $[2-4]$.

Modified bitumens for use as membranes for low-sloped roofs had their origins in Europe in the 1960s [1,5]. The present U.S. technology was, for the most part, imported from Europe in the 1970s at which time manufacturing began here [1]. The introduction of the modified bitumens occurred concurrently with the single-ply revolution in the U.S. roofing industry, when alternatives to conventional built-up roofing were sought [6]. Interestingly, as described by Johnson [1], the modified bitumen membranes are normally not used as true "single-plies," but are usually employed with a base ply. Nevertheless, some are applied in single-ply configuration. From little use a decade ago, U.S. annual installation of modified bitumens is now about 16 percent of membrane roofing [7]. Some projections indicate that their use by 1990 will be in the range of 27 to 33 percent of the area of membranes installed [5]. As an illustration of the rapid growth, the National Roofing Contractors Association's Roofing Materials Guide [8] indicated that, in August 1987, 158 modified bitumen products were available, whereas in February 1983, the number was 34.

Baxter [9] has recently reviewed the field performance of modified bitumen membrane systems. He stated that the overall performance has been acceptable, although not without problems. Some of the problems that he described were rupturing, slippage, blistering, separations at membrane flashing junctures, and lap separation and delamination. The CIB/RILEM ${ }^{2}$ Committee on Elastomeric, Thermoplastic, and Modified Bituminous Roofing also has reported on performance [10]. The Committee members described performance as generally being good to excellent. They indicated that problems experienced included some rupturing, blistering, shrinkage, and seam separation.

A major problem for the U.S. roofing industry has been the lack of consensus standards and criteria for selection and use of the polymer-modified bituminous roofing membrane materials [9]. Although performance has been generally satisfactory for the limited period of time that they have been available, the rapid growth in use has raised questions concerning long-term performance of materials which may enter the market without adequate evaluation [11]. Although consensus standards and related criteria for selection and use of the modified bitumens are not yet available in the United States, many documents [12-17] have been developed in North America and Europe which might provide the starting point for the U.S. industry. Also, a draft ASTM standard on methods for sampling and testing modified bitumens is presently under Subcommittee review [18].

The construction agencies of the U.S. Department of Defense (DOD) consider that benefits are to be gained in having available alternative materials for fabricating membranes for low-sloped roofing systems. However, they are reluctant to use the newer membrane materials such as the modified bitumens without having available selection criteria for guide specifications or other construction documents. The development of such criteria through ASTM or other industry organizations is not expected to be complete for many months. Thus, DOD requested that the National Institute of Standards and Technology (NIST) (formerly National Bureau of Standards/NBS) conduct a study to provide interim criteria for use in military guide specifications. This report presents the results of the study.

\footnotetext{
${ }^{1}$ These materials are frequently referred to as "modified bitumens," which is a term often used in this report.

${ }^{2} \mathrm{CIB}$ is a French acronym for Conseil International du Batiment pour la Recherche l'Etude et la Documentation; RILEM is a French acronym for Réunion Internationale des Laboratoires d'Essais et de Recherches sur les Materriaux et les Constructions.
} 


\subsection{Objectives}

The objectives of this report are:

- to provide a listing of documents that pertain to the development of selection criteria for modified bitumens, and to summarize the characteristics evaluated in the documents,

- to suggest selection criteria that may be used by the DOD construction agencies in the absence of voluntary consensus standards in the United States,

- to provide data that may assist in the development of voluntary consensus standards.

\subsection{Scope of the Sturdy}

The scope of the study focused on a review of standards and related documents (see sec. 2) which may serve as the basis for the development of interim selection criteria. As a first step in providing data to support the development of the suggested criteria, limited testing was conducted using typical commercially available modified bitumens.

The interim criteria suggested in the present report are not complete. When the study was initiated, it was realized that gaps would probably exist in the initial criteria proposed on the basis of a review of existing information. It was thought, at the time, that the available database for the characterization and evaluation of modified bitumens would be insufficient to support a complete set of criteria. For example, differing criteria on the same membrane property may be presented in two or more of the reference documents (existing standards), making it difficult to select one over the other on an interim basis without supporting laboratory testing. The gaps in the suggested criteria represent areas where research may be needed.

\subsection{Performance Specifications}

The criteria suggested herein are generally presented in performance criteria format, as developed for roofing membrane materials by Mathey and Cullen [12]. A performance specification defines a product in terms of the functions it is to perform; whereas a prescriptive specification defines a product in terms of its constituents and their relationships to each other [19]. A performance specification is considered to describe a product less narrowly than a prescriptive specification. Nevertheless, as discussed by Frohnsdorff et al. [19], prescriptive specifications frequently have the benefit of incorporating analyses (test methods) which can be conducted more rapidly than performance tests. In this regard, prescriptive specifications may be used for generic product characterization or identification. The criteria suggested herein are primarily in performance criteria format, but are complemented with prescriptive criteria.

\subsubsection{Performance Criteria Format}

The format used for presentation of the suggested performance criteria is that developed for bituminous built-up membranes in 1974 by Mathey and Cullen [12]. Their format for the performance approach had four key elements:

1. the requirement - a qualitative statement which describes what the membrane was to accomplish.

2. the criterion - a quantitative expression of the level of performance which the membrane should have to perform acceptably.

3. the test - the test method which was used to determine that the membrane conformed to the stated criterion.

4. commentary - to provide comment concerning an explanation of the reason for, or intent of, the stated criteria. 


\subsection{Modifiers and Reinforcements for Modified Bitumens}

The production of polymer-modified bituminous roofing membrane materials has been described in the literature [1-4]. The two primary modifiers currently used are: atactic polypropylene (APP) polymer and styrene-butadiene-styrene (SBS) block copolymer [3]. The APP modifier has constituted about 25 to 30 percent of the bitumen blend; whereas the SBS modifier has comprised about 8 to 14 percent of the blend [3]. The APP modifier is a plastomer, while the SBS modifier is an elastomer. In general, as described by Meynard [2], the modified bitumen displays elastomeric properties if the modifier is an elastomer, and plastic properties if the modifier is a plastomer. As a consequence, the elastomer-modified bitumens are usually more flexible and have greater elasticity at low temperatures; whereas the plastomer-modified bitumens are stiffer and have greater resistance to high temperatures [2].

The two major reinforcing mats used in polymer-modified bituminous roofing membrane materials are fibrous glass and polyester [2]. These reinforcements may be incorporated alone or together. As a consequence, the available membrane materials exhibit a wide variety of loadelongation properties ranging from high-strength/low-elongation to low-strength/high-elongation.

In conducting this study to present preliminary load-elongation and other criteria, the differences in modifiers and reinforcements were considered. However, in keeping with the performance concept, the suggested criteria are not divided along product lines varying by either modifier or reinforcement.

\section{STANDARDS AND RELATED DOCUMENTS FOR POLYMER- MODIFIED BITUMINOUS ROOFING MEMBRANE MATERIALS}

As indicated in the introduction, a number of standards and related documents have been developed for polymer-modified bitumens. It was considered that these documents could provide the basis for interim criteria for DOD use until a voluntary consensus standard is available in the United States. The standards and related documents reviewed during the present study, which formed the basis of the suggested criteria, are listed in table 4. As is evident, table 4 includes reference to the draft ASTM document ${ }^{3}$ on methods of test for the modified bitumens.

Table 4. Documents containing criteria applicable to bituminous roofing membranes

\begin{tabular}{lll}
\hline \hline Designation & \multicolumn{1}{c}{ Title } & Reference \\
\hline BSS 55 & Preliminary Performance Criteria for & [12] \\
UEAtc/Gen & General Directive for the Assessment of \\
& Roof Waterproofing Systems \\
UEAtc/SBS & Special Directives for the Assessment of \\
& Reinforced Homogeneous Waterproofing \\
& Coverings of Styrene-Butadiene-Styrene \\
(SBS) Elastomer Bitumen & [13] \\
UEAtc/APP & Special Directives for the Assessment of \\
& Reinforced Waterproofing Coverings of \\
Atactic Polypropylene (APP) Polymer Bitumen & Recommended Performance Criteria for \\
MRCA & Modified Bitumen Roof Membrane Systems \\
& Standard for Membrane, Modified, Bituminous, \\
CGSB & Prefabricated, and Reinforced for Roofing \\
& Standard Test Methods for Sampling and \\
Evaluating Modified Bituminous Materials for & Roofing and Waterproofing \\
\hline
\end{tabular}

\footnotetext{
${ }^{3}$ Used with the permission of the Chairman of ASTM Committee D08, which has responsibility for the draft.
} 
Table 5 presents a summary of the requirements incorporated in the standards and related documents of interest. Note that the majority of the requirements pertain to the properties of the finished membrane material. Other requirements are specific to a factory-applied membrane surfacing, the polymer-bitumen blend alone, and the reinforcement used for the sheet material.

Table 5. Summary of requirements given in the documents containing criteria applicable to bituminous roofing membranes

\begin{tabular}{|c|c|c|c|c|c|c|c|}
\hline \multirow[b]{2}{*}{ Requirement } & \multicolumn{7}{|c|}{ Document } \\
\hline & BSS 55 & $\begin{array}{l}\text { UEAlc } \\
\text { Ger }\end{array}$ & $\begin{array}{l}\text { UEAtc } \\
\text { SBS }\end{array}$ & $\begin{array}{l}\text { UEAtc } \\
\text { APP }\end{array}$ & $\begin{array}{c}\text { MRCA } \\
\text { MB }\end{array}$ & CGSB & $\begin{array}{c}\text { ASTM } \\
\text { draft }\end{array}$ \\
\hline Thickness & & & $\mathbf{x}$ & $\mathbf{x}$ & & & $\mathrm{x}$ \\
\hline Width & & & $\mathrm{x}$ & $\mathbf{x}$ & & & \\
\hline Mass per Area & & & $\mathbf{x}$ & $\mathbf{x}$ & & & \\
\hline Tensile Strength & $\mathbf{x}$ & & $\bar{x}$ & $x$ & $\mathbf{x}$ & $\mathbf{x}$ & $\mathbf{x}$ \\
\hline Elongation & & & $\mathbf{x}$ & $\mathbf{x}$ & $\mathbf{x}$ & $\mathbf{x}$ & $\mathbf{x}$ \\
\hline Strain Energy & & & & & $\bar{x}$ & $\mathbf{x}$ & $\mathbf{x}$ \\
\hline Thermal Expansion & $\mathbf{x}$ & & & & & $\mathbf{x}$ & \\
\hline Dimen. Stability & & $\mathbf{x}$ & $\mathrm{x}$ & $\mathbf{x}$ & & & $\mathbf{x}$ \\
\hline Shrinkage & & & $x$ & $\mathbf{x}$ & & & \\
\hline High Temp Stability & & & & & & & $x$ \\
\hline Flexural Strength & $\mathbf{x}$ & & & & & & \\
\hline Fatigue Strength & $\mathbf{x}$ & & $\mathbf{x}$ & $\mathbf{x}$ & & & \\
\hline Puncture-Static & & $\mathbf{x}$ & $\mathbf{x}$ & $\mathbf{x}$ & $\mathbf{x}$ & $\mathbf{x}$ & \\
\hline Puncture-Dynamic & $\mathbf{x}$ & $\mathbf{x}$ & $\mathrm{x}$ & $\mathbf{x}$ & $x$ & $\mathrm{x}$ & \\
\hline Impact & $\mathbf{x}$ & & & & $\mathbf{x}$ & & \\
\hline Abrasion & & & & & $\mathbf{x}$ & & \\
\hline Water Transmission & & $\mathbf{x}$ & & & $\mathbf{x}$ & & \\
\hline Moisture Content & & & & & & & $\mathbf{x}$ \\
\hline Moisture Absorption & & & & & $\mathbf{x}$ & $\mathbf{x}$ & $\mathbf{x}$ \\
\hline Tear Resistance & & $\mathrm{x}$ & $\mathbf{x}$ & $\mathbf{x}$ & & & $\mathbf{x}$ \\
\hline $\begin{array}{l}\text { Pliability } \\
\text { (low-temp flex) }\end{array}$ & & $x$ & $x$ & $x$ & $x$ & $x$ & $x$ \\
\hline Permeability & & $\mathbf{x}$ & $\mathbf{x}$ & $\mathbf{x}$ & $\mathbf{x}$ & $x$ & \\
\hline $\begin{array}{l}\text { Weathering Resist. } \\
\text { (durability) }\end{array}$ & & $\mathbf{x}$ & $\mathbf{x}$ & $\mathbf{x}$ & $\mathbf{x}$ & $\mathbf{x}$ & $\mathbf{x}$ \\
\hline Heat Resistance & & & $\mathrm{x}$ & $\mathbf{x}$ & $\mathbf{x}$ & & $\mathrm{x}$ \\
\hline Chemical Resistance & & & & & $x$ & & \\
\hline Seam Strength & & $\mathbf{x}$ & $\mathbf{x}$ & $\mathbf{x}$ & $\mathbf{x}$ & $\mathbf{x}$ & \\
\hline Seam Leakage & & $\mathbf{x}$ & $\mathbf{x}$ & $\mathbf{x}$ & & & \\
\hline Flow Resistance & & $\mathrm{x}$ & $\mathbf{x}$ & $\mathbf{x}$ & $\mathbf{x}$ & & \\
\hline Thermal Shock & $\mathbf{x}$ & $x$ & $\mathbf{x}$ & $\mathbf{x}$ & $\mathrm{x}$ & & \\
\hline Cyclic Movement & & I & & & $\mathbf{x}$ & $\mathrm{x}$ & \\
\hline Plant Growth & & $\mathbf{x}$ & & & & & \\
\hline Temp-Induced Load & & & & & $\mathrm{x}$ & & \\
\hline Fire & $\mathbf{x}$ & $\mathbf{x}$ & $\mathrm{x}$ & $\mathbf{x}$ & $\mathbf{x}$ & & \\
\hline Uplift (Wind) & $\mathbf{x}$ & $\mathbf{x}$ & $\mathbf{x}$ & $\mathbf{x}$ & $\mathbf{x}$ & & \\
\hline Peel (Wind) & & $\mathbf{I}$ & $\mathbf{x}$ & $\mathbf{x}$ & & & \\
\hline Peel (Wind) & & $\mathbf{x}$ & $\mathbf{x}$ & $\mathbf{x}$ & & & \\
\hline Foil Integrity & & & & & $x \quad x$ & & \\
\hline Granule Embedment & & & $x$ & $x$ & & $\mathbf{x}$ & $\mathbf{x}$ \\
\hline Coating Fines & & & $x$ & $\mathrm{x}$ & & & \\
\hline Softening Point & & & $\mathbf{x}$ & $\mathbf{x}$ & & & \\
\hline Penetration & & & & $\mathbf{x}$ & & & \\
\hline Low-Temp. Flex. & & & $\mathbf{x}$ & $\mathbf{x}$ & & & \\
\hline Elastic Recovery & & & $\mathbf{x}$ & $\mathbf{x}$ & & & \\
\hline Reinfor. Mass & & & $\mathbf{x}$ & $x$ & & & \\
\hline Stress/Elongation & & & $\mathbf{x}$ & $\mathrm{x}$ & & & \\
\hline
\end{tabular}


From table 5, it is evident that the requirements for testing considered in the ASTM draft have been included in many of the other documents referenced. Two exceptions are high-temperature stability and moisture content which appear only in the ASTM draft. Because the primary intent of the ASTM draft is to recommend test methods for characterization of membrane material as it is manufactured, the ASTM document does not include systems-related tests such as puncture resistance, cyclic movement, and strength of seams.

In the development of the criteria suggested herein, chief consideration was given to the use of test methods under review by ASTM. This approach was taken in order to promote compatibility between interim criteria suggested in the present report and voluntary consensus requirements likely to be recommended by ASTM Committee D08. As the present report was under preparation, the ASTM draft was near to consensus agreement at the Subcommittee level. It has been widely debated, and few future changes are expected. To support the use of the ASTM draft methods in the suggested criteria, some preliminary testing was conducted in the present study. The results of the tests conducted are presented in Appendix A.

\section{SUGGESTED INTERIM CRITERIA}

This section of the report presents interim criteria to assist in the selection and use of polymermodified bituminous roofing membrane materials. The criteria are divided into two categories: 1) prescriptive criteria concerning the characterization of the material as manufactured, and 2) performance criteria concerning properties associated with in-service behavior. In addition, a third category is provided whereby performance requirements are listed, but the associated criteria are not yet suggested. In the latter case, as mentioned, it was considered that sufficient data were not available to support suggesting criteria at this time.

\subsection{Prescriptive Requirements for Characterization}

Polymer-modified bituminous roofing membrane materials are produced in plants where quality control procedures may be applied to ascertain that they have certain physical, mechanical, and chemical properties. A key step in the quality control process is testing used to characterize the product. Quality control testing is beneficial to both the manufacturer and consumer. Among other factors, it assures a degree of uniformity of the product, and consistent properties from batch to batch. However, in the case of U.S. roofing products, specifications based on the quality control tests historically provide only prescriptive criteria used to characterize the manufactured product, and do not consider the performance requirements of the membrane material in service [20].

One benefit of prescriptive criteria is that they provide a means to assure that the product reaching the market has the selected property values agreed upon between seller and buyer. Moreover, as Frohnsdorff et al. [19] indicated, test methods for prescriptive criteria are often more practical than performance tests for routine product characterization.

Some requirements may serve a dual role, relating both to prescriptive characterization and performance of the material. An example is low-temperature flexibility. In this case, a product, as manufactured, may have a low-temperature flexibility inherently lower than that needed to perform satisfactorily under expected service conditions. Two ways of specifying the property value are apparent. First, the actual low-temperature flexibility point may be specified as a means of product identification or characterization. Second, the specification may reference the low-temperature flexibility point considered necessary for acceptable performance, which any material should meet.

Quality control tests have been developed in Europe to characterize the properties of modified bitumens $[14,15]$. Not only are the composite sheets characterized through these tests, but also the individual components comprising the sheets such as reinforcements, modified-bitumen binder, and protective surfacings. 
Examples of the prescriptive characterization tests in the UEAtc documents (table 5) for polymer modified bitumens include [14,15]:

A) Membranes

- thickness

- width of sheet

- mass per unit area

- tensile strength and elongation at break

- tearing strength

- low-temperature flexibility

B) Polymer-Bitumen Blend

- fines content

- ring-and-ball softening point

- low-temperature flexibility

- elastic recovery

C) Reinforcements

- nature

- mass per unit area

- ultimate stress and elongation at break

At present, the ASTM draft document [18] on modified bitumens has included a number of tests considered in the category of prescriptive requirements for membrane material characterization. The tests are:

- thickness,

- tensile load,

- tensile elongation,

- low-temperature flexibility, and

- tear resistance.

Requirements for characterizing modified bitumens using these five properties are included in the interim criteria as a complement to the suggested performance criteria.

From table 5 it may be noted that the list of requirements in the ASTM draft is less than those from the UEAtc documents for APP-and SBS-modified bitumens [14,15]. A contributing factor is that the UEAtc requires characterization of the bitumen blend and reinforcement, as well as the composite sheet. Consideration of requirements for bitumen blends and reinforcements was beyond the scope of the present study. Future modification of the criteria suggested herein could consider inclusion of requirements pertaining to the polymer-bitumen blend or the reinforcement, as was done in Europe.

Table 6 presents the suggested prescriptive requirements associated with the selected tests given in the ASTM draft. As seen in table 6, the requirements for thickness, tensile load, tensile elongation, low-temperature flexibility, and tear resistance are that the average $e^{4}$ measured property values of the membrane product, as supplied to the user, should not be less than (or where appropriate, greater than) a given percentage of the stated nominal values as described by the manufacturer (perhaps in the product literature or in the NRCA Materials Guide) for the membrane material. This approach is considered more practical for assuring that the material supplied to a DOD agency is that normally produced by the manufacturer, than if the requirement specified a minimum property value. For example, take a hypothetical case that a sheet material have a required minimum thickness of 0.12 in $(3 \mathrm{~mm})$. In this example, a product usually manufactured at 0.16 in $(4 \mathrm{~mm})$ could be supplied at a thickness 25 percent thinner than normally produced, and still meet a specification calling for a 0.12 in $(3 \mathrm{~mm})$ minimum.

Note that, in table 6, the requirements for thickness, low-temperature flexibility, and tear resistance have included a suggested limiting value for all products. These limiting values were based on the results of tests in this study for typical commercially available material. These materials are considered representative of those available currently in the U.S. industry. Future experience could result in suggested revisions of these limiting values.

\footnotetext{
${ }^{4}$ The number of tests are as suggested in the proposed ASTM test methods.
} 
Prescriptive criteria, specified according to the "nominal" property values, provide a means of tighter control of the specified product. This is attractive for specifying modified bitumens, since so many materials are available, and collectively, their prescriptive properties cover a wide range of values. This approach to specifying prescriptive requirements as related to described property values is not novel, but has been used by the UEAtc [14,15]. A form of this approach has also been used at ASTM. However, in the case of ASTM, the specification usually indicates that the specified value of a given property be agreed upon between buyer and seller, with perhaps a minimum or maximum value being required.

Table 6. Prescriptive requirements for polymer-modified bituminous roofing membrane materials

\begin{tabular}{|c|c|c|}
\hline Property & Prescriptive Requirement & $\begin{array}{l}\text { ASTM } \\
\text { Method }\end{array}$ \\
\hline Thickness & $\begin{array}{l}\text { The average thickness shall not be less } \\
\text { than } 5 \% \text { of the nominal value as stated by } \\
\text { the product manufacturer; the minimum } \\
\text { shall be } 0.040 \text { in }(1 \mathrm{~mm}) \text {. }\end{array}$ & Sec. 5 \\
\hline Loade max. & $\begin{array}{l}\text { The average maximum load shall not be } \\
\text { less than } 15 \% \text { of the nominal value as } \\
\text { stated by the product manufacturer. }\end{array}$ & Sec. 6 \\
\hline Elongation ${ }^{c}$ at max. load & $\begin{array}{l}\text { The average elongation at maximum load } \\
\text { shall not be less than } 20 \% \text { of the nominal } \\
\text { value as described by the product } \\
\text { manufacturer. }\end{array}$ & Sec. 6 \\
\hline Elongation ${ }^{c}$ at break & $\begin{array}{l}\text { The average elongation at break shall not } \\
\text { be less than } 20 \% \text { of the nominal value as } \\
\text { described by the product manufacturer. }\end{array}$ & Sec. 6 \\
\hline Low-Temperature Flexibility & $\begin{array}{l}\text { The low-temperature flexibilityd shall } \\
\text { not be more than } 5^{\circ} \mathrm{F}\left(3^{\circ} \mathrm{C}\right) \text { above the } \\
\text { nominal the value as described by the } \\
\text { product manufacturer, the maximum shall } \\
\text { be } 25^{\circ} \mathrm{F}\left(-4^{\circ} \mathrm{C}\right) \text {. }\end{array}$ & Sec. 11 \\
\hline Tear Resistance & $\begin{array}{l}\text { The average tear resistance shall not be } \\
\text { less than } 20 \% \text { of the nominal value as } \\
\text { described by the product manufacturer; } \\
\text { the minimum shall be } 30 \mathrm{lbf}(130 \mathrm{~N}) \text {. }\end{array}$ & Sec. 8 \\
\hline
\end{tabular}

\footnotetext{
${ }^{2}$ Method as given in the ASTM draft document [18]. As the present report was prepared, the ASTM draft was near to consensus agreement at the Subcommittee level. It has been widely debated, and few future changes are expected.

B Average of five measurements.

' In tension.

No cracking for five specimens.
}

\subsection{Suggested Interim Performance Criteria}

This section of the report presents suggested interim performance criteria for modified bitumens. The list was based on reviewing the documents listed in section 2. Test methods referenced from ASTM and UEAtc are given in Appendix B and Appendix C, respectively.

The membrane and system characteristics for which criteria are suggested are:

- dimensional stability

- fire resistance

- flow resistance

- hail impact resistance

- moisture content and absorption

- pliability

- strain energy

- uplift resistance

- weathering resistance-heat exposure. 
Some of the criteria, notably those on fire, flow, hail, strain energy, and uplift pertain to the modified bitumen as used in the roof system. The remainder are specific to the membrane material alone. It is realized that the list may be more extensive than DOD can conveniently apply to common use in guide specifications. One suggestion is that a core list of criteria be used in guide specifications, and that it be complemented, as necessary, on a case by case basis with other criteria.

\subsubsection{Dimensional Stability}

Requirement The roof membrane shall not exhibit large irreversible dimensional change when exposed to temperatures encountered under normally expected service conditions.

Criterion The linear dimensional change shall not be more than $\pm 1 \%$.

Test $\quad$ ASTM proposed method of test, section 10 [18].

Commentary Membrane materials may not be dimensionally stable, and undergo irreversible expansion or contraction in service. For example, shrinkage can result in stress in the membrane material and subsequent cracking, as well as loss of adhesion between components. Expansion can result in unwanted ridges and buckles that may crack or split, or be damaged by foot traffic and other user loads. Heat exposure is a major environmental factor which may result in irreversible dimensional change.

\subsubsection{Fire Resistance}

Requirement The roofing system shall not pose an undue safety hazard when exposed to fire conditions.

Criterion The system shall meet the requirements specified by the applicable building code concerning fire resistance (or local military regulations).

Test The test shall be conducted using nationally recognized procedures such as those developed by ASTM, Underwriters Laboratories (UL), or Factory Mutual (FM).

Commentary Test procedures for fire resistance, developed by ASTM, UL, or FM, have been widely used by the roofing industry, and are generally accepted by the construction industry [12].

\subsubsection{Flow Resistance}

Requirement The roofing system shall resist slippage forces generated during service due to factors such as roof slope and elevated temperature exposure.

Criterion No slippage (movement) shall occur, as tested.

Test UEAtc M.O.A.T. No. 27, section 5.1.7 [13].

Commentary This test is intended for membrane systems installed with slopes. The test need not be conducted on roof systems that have the membrane mechanically anchored in place.

Experience has shown that bituminous membrane materials may readily undergo slippage under certain conditions of use [21]. Slippage has been defined as "relative lateral movement of adjacent components of a built-up membrane" [22]. Slippage occurs mainly in roofing membranes on a slope, sometimes exposing the lower plies to the weather [22]. It is associated with the viscosity of the bitumen and other factors such as membrane surfacing and roof-top temperatures [21]. 


\subsubsection{Hail Impact Resistance}

Requirement The roofing system shall be capable of withstanding, without loss of waterproofing integrity, normally encountered hail impact loads due to environmental exposure.

Criterion a) The roof membrane shall be able to withstand an impact of a 1.5 in (38 $\mathrm{mm})$ diameter hailstone falling at a speed of $112 \mathrm{ft} / \mathrm{s}(34 \mathrm{~m} / \mathrm{s})$ without allowing water penetration [12].

or

b) The roof membrane shall withstand an impact of $22 \mathrm{lbf} \cdot \mathrm{ft}(30 \mathrm{~J})$ from a freely falling tup without allowing water penetration.

Tests a) Hail impact-NBS hail resistance test, Building Science Series 23 and Building Science Series 55.

or

b) Falling Missile Impact-ASTM D 3746.

Commentary The hail impact criterion was first proposed for bituminous built-up membranes [12]. This test is of particular importance where the membrane is used in areas subjected to hail storms.

Koontz [23] has conducted comparative testing of newer roofing membrane materials using both the hail impact and falling missile tests. He reported that comparable results were observed using the two procedures.

In cases where it is questioned whether the membrane material is no longer watertight after the impact test, a watertightness test [24] may be conducted.

\subsubsection{Moisture Content and Absorption}

Requirement The moisture absorbed by the membrane in service shall not adversely affect its performance over the service life of the system.

Criteria a) The moisture content of the membrane material shall not exceed 0.5 percent by mass.

b) The water absorption of the membrane shall not exceed 1 gram (for the given specimen size).

Tests a) ASTM proposed method of test, section 8 [18].

b) ASTM proposed method of test, section 9 [18].

Commentary Experience has shown that elevated moisture contents in bituminous membrane materials may have an adverse effect on both proper application of the membrane and also its performance in service [25]. The suggested criterion for water absorption was originally proposed in the MRCA Criteria [16] and the Canadian Standard [17] for modified bitumens. 
Requirement The membrane material must be capable of being readily unrolled, flexed and bent without damage during application under normally expected environmental conditions.

Criteria a) Low-temperature flexibility - The temperature at which cracking occurs shall not be less than the temperature at which the membrane material is to be installed.

b) Unrolling at low-temperature-The membrane material shall be unrolled without cracking or tearing at $32^{\circ} \mathrm{F}\left(0^{\circ} \mathrm{C}\right)$.

Test $\quad$ a) ASTM proposed method of test, section 11 [18].

b) UEAtc M.O.A.T. No. 27, section 5.4.3 [13].

Commentary Membrane materials are delivered to the job site in roll form where they are unrolled during installation under temperature conditions which may reach $32^{\circ} \mathrm{F}$ $\left(0^{\circ} \mathrm{C}\right)$ or lower. Low temperatures can result in embrittlement of the membrane material. Installation of the membrane should be avoided under low temperature conditions below which it may be embrittled and consequently damaged, e.g., cracking or splitting. This is of particular concern with base flashing materials whereby extremely sharp bends may be imposed on the materials. In general, APP-modified bitumens and SBS-modified bitumens have low-temperature flexibility points less than $23^{\circ} \mathrm{F}\left(-4^{\circ} \mathrm{C}\right)$ and $5^{\circ} \mathrm{F}\left(-15^{\circ} \mathrm{C}\right)$, respectively $[14,15]$. Under some circumstances, application of the membrane material might be conducted at air temperatures below the low-temperature flexibility point, provided adequate external heat can be provided to keep the material pliable.

\subsubsection{Strain Energy}

Requirement The roof membrane shall withstand, without rupture, the normal stresses imposed from internal or external causes.

Criterion The strain energy of the composite membrane material shall not be less than 3 $\mathrm{lbf} \cdot \mathrm{in} / \mathrm{in}^{2}\left(0.5 \mathrm{kN} \cdot \mathrm{m} / \mathrm{m}^{2}\right)$ in the weaker direction of the membrane when tested at $0^{\circ} \mathrm{F}$ $\left(-18^{\circ} \mathrm{C}\right)$; in addition, the membrane shall remain watertight after elongation at $0^{\circ} \mathrm{F}$ $\left(-18^{\circ} \mathrm{C}\right)$ to a percent at which the strain energy is equivalent to the criterion strain energy of $3 \mathrm{lbf} \cdot$ in $/ \mathrm{in}^{2}\left(0.5 \mathrm{kN} \cdot \mathrm{m} / \mathrm{m}^{2}\right)$.

Test $\quad$ ASTM proposed method of test, section 6 [18].

Commentary This test should be conducted on the composite membrane. Only in cases where the modified bitumen material is installed as a single-ply membrane should the test be conducted on the single sheet alone.

Certain membranes exhibit anisotropic behavior. Therefore, the results of tests in the weaker direction should apply. Excessive elongation of the membrane may cause cracking of the bitumen and loss of watertightness. Thus, a watertightness test is conducted at a percent elongation corresponding to the minimum strain energy.

Strain energy is a measure of the ability of the membrane to resist energy loads before rupture. It is related to the toughness of the material, taking into consideration both strength and strain capacity of the membrane. It is determined in a tension test as the area under the load-elongation curve.

The CIB/RILEM Committee [10] has indicated that the load-strain product offers an approach for evaluation of a membrane's ability to resist expansion generated by movement of the support below the membrane, but suggested that research is needed to provide the basis for use of the approach. Rossiter and Bentz [24] and Lee and Dupuis [26] have investigated the use of strain energy as a performance criterion for bituminous membranes. From their study, Lee and Dupuis proposed the use of strain energy as a means of having a safety factor for a membrane's ability to resist energy loads. Wells [27] recently reported on the preliminary results of an analytical study which indicated that a low strain energy value of $2 \mathrm{lbf}$ in $/$ in $^{2}\left(0.4 \mathrm{kN} \cdot \mathrm{m} / \mathrm{m}^{2}\right)$ may not be universal to all membrane materials. The criterion suggested above, 3 $\mathrm{lbf} \cdot \mathrm{in}_{\mathrm{in}} \mathrm{in}^{2}\left(0.5 \mathrm{kN} \cdot \mathrm{m} / \mathrm{m}^{2}\right)$, was previously given as preliminary and that further research may provide a revised value of strain energy as a performance criterion [24]. Note that units of strain energy given herein account for gage length and width of the test specimen. 


\subsubsection{Uplift Resistance}

Requirement The roof system shall withstand design uplift forces without adverse effect.

Criterion The system shall meet the requirements specified by applicable building codes concerning uplift resistance (or local military regulations).

Test The test shall be conducted using nationally recognized procedures developed by ASTM, Underwriters Laboratories (UL), or Factory Mutual.

Commentary Test procedures for uplift resistance, developed by ASTM, UL, or FM, have been widely used by the roofing industry, and are generally accepted by the construction industry [12]. The requirement for uplift resistance will depend, among other factors, on the local wind conditions to which the roofing system will be exposed. Some local jurisdictions may have code requirements more stringent than national model codes because of local wind conditions.

\subsubsection{Weathering Resistance - Heat Exposure}

Requirement The membrane shall be capable of sustaining exposure to normally encountered temperatures without significant loss of performance properties.

Criteria a) Load-elongation properties - the load-elongation properties shall not change by more than 15 percent from those determined for the unexposed material.

b) Low-temperature flexibility-the low-temperature flexibility of the exposed membrane material shall not exceed $32^{\circ} \mathrm{F}\left(0^{\circ} \mathrm{C}\right)$.

c) Strain energy - the strain energy of the membrane incorporating the heat aged modified sheet shall not be less than $3 \mathrm{lbf} \cdot \mathrm{in} / \mathrm{in}^{2}\left(0.5 \mathrm{kN} \cdot \mathrm{m} / \mathrm{m}^{2}\right)$.

Test $\quad$ ASTM proposed method of test, section 12 [18].

Commentary European experience has indicated that, for modified bitumens, oxidation in air is considered to be a major agent causing the deterioration of the membrane material [2,13-15,28]. This property is evaluated using a heat aging test in air. The ASTM draft list of test methods for modified bitumens has included a heat aging procedure and suggests determining load, elongation, strain energy, and low-temperature flexibility before and after exposure.

The criteria suggested for these properties have had considerable use in the roofing industry. The criterion for changes of load-elongation properties was included in the MRCA criteria [16]. The criterion on low-temperature flexibility was included in the UEAtc documents [14,15]. A previous NBS (now NIST) study [23] has suggested that the strain energy of exposed membrane materials not be less than $3 \mathrm{lbf} \cdot \mathrm{in} / \mathrm{in}^{2}(0.5$ $\mathrm{kN} \cdot \mathrm{m} / \mathrm{m}^{2}$ ).

\subsection{Needed Criteria for Future Development}

The membrane requirements for which criteria are considered to be needed, but were not developed in the present report are:

- cyclic (substrate) movement resistance

- durability of protective surfacings

- puncture resistance

- seam strength

- slippage resistance of base flashings

- tear resistance

- water transmission resistance

- weather resistance (except heat exposure).

Because of the importance of having criteria for these requirements, an initial step in outlining performance criteria using the standard format was undertaken, but the criteria themselves were not proposed. With the exception of cyclic movement resistance, for each of the requirements listed above, the criteria are described as "not established." In most cases, test methods upon which the 
criteria may be based have been suggested. In a few cases, the test methods are also noted as "not established." As previously indicated, a benefit in presenting this outline of needed criteria is to define the gaps for future criteria development and the needs for research to develop performance data. As future development of the criteria continues, the results should be incorporated into DOD guide specifications.

\subsubsection{Cyclic Movement Resistance}

Requirement The roofing membrane shall resist the movement of the membrane substrate encountered during normal service conditions without splitting, tearing, cracking, or undue deformation.

Criterion When tested, no loss of waterproofing through splits, cracks, tears, buckling, and similar defects shall occur in the membrane. In addition, total loss of adhesion of the membrane material to the substrate shall not occur.

Test UEAtc M.O.A.T. No. 27, section 5.1.8 [13].

Commentary The CIB/RILEM Committee has considered that the ability of roofing membranes to withstand expansion and contraction generated by cyclic movement of the membrane substrate is among the more important properties concerning membrane performance [10]. Factors influencing cyclic movement resistance include the amplitude and frequency of the cycle, and the temperature of the test. Characteristics of the polymer-modified bituminous roofing membrane materials which affect their performance in cyclic movements tests are the type of reinforcement and its location in the sheet, as well as the bitumen itself. The evaluation of the ability of modified bitumens to resist cyclic movement may allow the classification of these materials into categories depending upon the extent of expected movement in service [10].

The UEAtc evaluation procedure [13] in the test procedure allows for minor cracking and buckling (no loss of watertightness), or partial loss of adhesion to occur during the test. Guidance is given that such occurrence should be evaluated on an individual basis. This test is not conducted on loose-laid membranes.

This test for resistance to cyclic movement has received little attention in the U.S. roofing industry. Data are needed to support the suggested criterion and implement its use. It should be kept in mind that the suggested criterion comes from Europe (UEAtc General Directives), as have many of the modified bitumens on the U.S. market. The products of European origin may have undergone cyclic movement evaluation under the Agrement system in Europe.

\subsubsection{Durability of Protective Surfacings}

Requirement Factory-applied protective surfacings on polymer-modified bituminous roofing membrane materials shall provide protection to the membrane over the service life of the roof system.

Criteria a) Granular protection-not established.

b) Foil protection-not established.

Tests a) Granular protection-ASTM proposed method of test, section 15 [18].

b) Foil protection-CGSB method of test, section 7.2.6 [17].

Commentary Many of the modified bitumens have a factory applied surfacing to provide protection from ultraviolet radiation. The typical surfacings are roofing granules and metal foils. The surfacing should remain intact over the service life of the membrane to prevent premature deterioration. Loss of factory-applied protective surfacings in service could result in rapid deterioration of the membrane. The test procedure for foil prote ution was included in both the MRCA [16] and CGSB [17] documents. Of the two, only the CGSB standard had a requirement for granule embedment. 
Requirement The roofing system shall be capable of withstanding, without loss of integrity, the normally encountered static and dynamic puncture loads due to use and environmental exposure.

Criteria a) Static puncture-not established.

b) Dynamic puncture-not established.

Tests a) Static puncture-UEAtc method of test, section 5.1.9.

b) Dynamic puncture-French standard NF P 84-353.

Commentary The CIB/RILEM Committee [10] considered that puncture resistance is a key performance characteristic to be included in the evaluation of roofing membrane materials. Puncture loads may either penetrate the waterproofing integrity of the membrane, or result in undue deformation [13]. Puncture loads may arise from two sources: environmental exposure (e.g., falling tree limbs) and use of the roof (e.g., foot traffic).

Both static and dynamic puncture loads should be considered. Static loads are both relatively short term (e.g., foot traffic) and long term (e.g., ladders). Dynamic loads are of the impact type (e.g., dropping of tools). Two factors which influence puncture resistance are softening of the membrane material at elevated temperatures and the possible deformation of the membrane support.

The test procedures listed above have been recommended by the CIB/RILEM Committee. Criteria have not been established, but the Committee suggested that membranes may be classified in an increasing order of puncture resistance using the cited tests.

\subsubsection{Seam Strength}

Requirement Seams in single-ply membranes shall be watertight over the service life of the membrane.

Criterion Not established.

Test Not established.

Commentary The ability of seams in single-ply membranes to remain watertight is critical, since a delamination will result in a roof leak. Note that some modified bitumens are employed in single-ply roofing configurations. Evaluation of this property is not needed in cases where the modified bitumen is used in a multi-ply system.

Both the UEAtc general directives [13] and MRCA criteria [16] have included seam characterization using a lap-shear test. Recent investigations of the use of the lapshear test for evaluating the quality of adhesive-bonded seams in rubber membranes indicated that the procedure is not sensitive to various application conditions expected to affect bond strength adversely [29]. Considering this finding, the use of the lap-shear test for evaluating seams of modified bitumens is not included in the criteria in the present report. It is considered that the applicability of this test method or an improved method needs to be established. 
Requirement When used as base flashing, the modified bitumen material must be capable of resisting creep and tearing forces generated under service conditions.

Criterion Not established.

Test

Commentary In addition to their use as membrane materials, modified bitumens are also used as base flashings on vertical surfaces. The base flashing should remain in place without undue slippage and tearing at mechanical fasteners which may be used to secure the flashing in place. This property is temperature dependent. Elevated temperatures may soften polymer modified bitumens producing slippage, drippage, accelerated creep, and lowered resistance to tearing. Research is needed to provide the data to establish the criterion.

\subsubsection{Tear Resistance}

Requirement The membrane material shall have sufficient strength to allow handling without damage under normal installation conditions, and withstand normally expected tear loads encountered in service.

Criterion Not established.

Test Not established; suggested tests are the ASTM proposed method of test, section 7 [18], and the UEAtc procedure [13].

Commentary Roof systems are installed under a variety of environmental conditions using extensive manual labor that can impart tear loads through tugging and pulling during application. Membrane materials with low tear resistance may not adequately survive the rigors of installation and be easily damaged during handling on site.

Membranes, particularly those partially attached, may be subjected in service to tear forces because of factors such as wind flutter, shrinkage, and thermal movement.

The CIB/RILEM Subcommittee has recommended that the UEAtc procedure be used to evaluate this property. However, no criterion was suggested. Measurements and analysis of tear forces in service may be needed to help provide a basis for the criterion.

\subsubsection{Resistance to Water Transmission}

Requirement The roofing membrane shall prevent the penetration of water through the roofing system.

Criterion The membrane shall be watertight, as tested.

Test Not established; suggested tests include those in the UEAtc [13], MRCA [16], and CGSB [17] documents.

Commentary The ability of the membrane to keep the roof watertight is its basic function. Unwanted pinholes may be incorporated into the membrane material during manufacture and provide pathways for water transmission into the system. This criterion is intended to evaluate this property.

Since pinholes may expand upon heating and possibly lower the resistance of the membrane material to prevent water transmission, it may be of interest to evaluate this property after subjecting the membrane material to temperatures comparable to those encountered during application to its substrate.

A test procedure is not suggested at this time from those available, because of the subtle differences which exist between those listed above. For example, a water column (head of water) test is normally used. However, the height of the column differs in each of the cited tests. In addition, the utility of a water column test for detecting pinhole faults in membranes has been questioned [30]. 


\subsubsection{Weathering Resistance (except heat exposure)}

Requirement The membrane material shall be capable of sustaining exposure to normally encountered environmental agents including ultraviolet (UV) radiation, moisture, chemical pollutants, and fungus without significant loss of performance properties.

Criteria a) UV exposure-not established.

b) Moisture exposure - not established.

c) Chemical exposure-not established.

d) Fungus growth - not established.

Tests a) UV exposure-not established.

b) Moisture exposure-not established.

c) Chemical exposure-not established.

d) Fungus growth - not established.

Commentary During service, roofing membrane systems are subjected to a wide variety of environmental agents such as temperature, ultraviolet radiation, moisture, gases, and chemical pollutants which can cause deterioration of performance properties. Research is needed to develop predictive methodologies for evaluating the long-term serviceability of membrane materials [11]. At present, the ASTM draft list of methods includes a UV resistance test. Because experience in applying the test to modified bitumens is limited, the ASTM draft proposal on UV resistance is not included in the present document.

When considering weathering tests, the European experience with modified bitumens offers some approaches that may be considered in performance tests:

a) ultraviolet radiation. The upper surfaces of modified bitumens may or may not be left exposed depending upon the membrane system. In the UEAtc system $[14,15]$, consideration of the potential deleterious effects of UV radiation is considered necessary in cases where the top ply of the membrane is directly exposed to solar radiation. It is noted that SBS membrane materials normally have a protective covering; whereas APP membrane materials are used, at times, directly exposed to the sun without a covering.

The UEAtc documents $[14,15]$ consider that the resistance to UV radiation is deemed satisfactory if the membrane:

1) is used under aggregate surfacing, or

2) contains its own protection (i.e., granules or foil) incorporated during manufacture.

In these cases, the UEAtc documents do not contain requirements for conducting UV tests.

b) moisture. Moisture is considered to be among the key environmental factors causing deterioration of building materials. European experience with modified bitumens has indicated that water has not, in general, adversely affected the performance characteristics of the modified bitumens, provided that the reinforcement is sufficiently impregnated and coated. The UEAtc documents $[14,15]$ indicated that testing of modified bitumens is carried out only in cases where concern exists that water could have an adverse effect on an individual product. Key changes in performance characteristics of the membrane material considered to be affected are loss of:

1) low-temperature flexibility,

2) bitumen adhesion to the reinforcement, and

3) granule embedment.

c) chemical agents. Depending upon building use and location, a roofing system may be subjected to chemical agents such as industrial oils, and environmental pollutants which could adversely affect performance. This property has received little attention in Europe. For example, the UEAtc special directives [14,15] have no requirements for evaluating the resistance to chemical agents. The MRCA document [16] suggests that, when chemical resistance is of concern, the membrane manufacturer be asked to provide a list of agents that may be harmful.

d) fungal growth. Experience has shown that certain environmental conditions may promote the growth of fungus on the roof surface. In cases where concern exists that fungal growth could occur, the resistance of the membrane (or its protective surfacing) should be evaluated. The European documents do not address this criterion $[14,15]$. Procedures need to be developed. 


\section{SUMMARY AND CONCLUSIONS}

This report has presented the results of a study to develop interim criteria for the selection of polymer-modified bituminous roofing membrane materials. The criteria are intended for use by the construction agencies of the Department of Defense in specifying modified bitumens until voluntary consensus standards are developed in the United States.

The criteria were suggested on the basis of performance considerations for low-sloped roofing. Thus, the suggested interim criteria were generally presented using a performance criteria format. This format was first developed in the early 1970 s for bituminous built-up membranes. Although the various products available to the U.S. roofing industry may use different polymer modifiers and reinforcements, the suggested criteria are not divided into classifications based on modifier or reinforcement. Future expansion of the performance concept to modified bitumens may allow their classification into categories concerning performance properties, e.g., low or high resistance to puncture or cyclic movement. Such classification could reflect differences between modifiers or reinforcements.

Prescriptive criteria for five membrane characteristics were used to complement the suggested performance criteria. These characteristics were thickness, tensile load, tensile elongation, low-temperature flexibility, and tear resistance. The approach of using complementary prescriptive criteria was taken to incorporate into the performance criteria test methods which can be relatively rapidly performed for characterization or identification of the membrane material. Table 7 provides a summary of the prescriptive and performance criteria and tests suggested in the study.

Table 7. Summary of suggested prescriptive and performance criteria for modified bitumens

\begin{tabular}{|c|c|c|}
\hline Requirement & Test Method & Criterion \\
\hline Thickness & ASTM draft, Sec. 5 & $\begin{array}{l}\text { not }<5 \% \text { of the nominal value, } 40 \mathrm{mil} \\
(1 \mathrm{~mm}) \text { minimum }\end{array}$ \\
\hline Load, max. & ASTM draft, Sec. 6 & not $<15 \%$ of the nominal value \\
\hline Elongation (max. load) & ASTM draft, Sec. 6 & not $<20 \%$ of the nominal value \\
\hline Elongation (break) & ASTM draft, Sec. 6 & not $<20 \%$ of the nominal value \\
\hline Low-Temperature Flexibility & ASTM draft, Sec. 11 & $\begin{array}{l}\text { not }>5^{\circ} \mathrm{F}\left(3^{\circ} \mathrm{C}\right) \text { of nominal, } 25^{\circ} \mathrm{F} \\
\left(-4^{\circ} \mathrm{C}\right) \text { maximum }\end{array}$ \\
\hline Tear Resistance & ASTM draft, Sec. 7 & $\begin{array}{l}\text { not }<20 \% \text { of the nominal value } 30 \mathrm{lbt} \\
(130 \mathrm{~N}) \text { minimum }\end{array}$ \\
\hline Dimensional Stability & ASTM draft, Sec. 10 & $\max$. change, $\pm 1 \%$ \\
\hline Fire Resistance & ASTM, UL or FM test & conform to applicable code \\
\hline Flow Resistance & $\begin{array}{l}\text { UEAtc No. } 27 \\
\text { Sec. } 5.1 .7\end{array}$ & no slippage \\
\hline \multirow[t]{2}{*}{ Hail Impact } & $\begin{array}{l}\text { NBS BSS } 55 \\
\text { or }\end{array}$ & $\begin{array}{l}1.5 \mathrm{in}(38 \mathrm{~mm}) \text { hail stone at } 112 \mathrm{ft} / \mathrm{s} \\
(34 \mathrm{~m} / \mathrm{s}) \text { without water penetration }\end{array}$ \\
\hline & ASTM D 3746 & $\begin{array}{l}22 \mathrm{lbf} \cdot f t(30 \mathrm{~J}) \text { without water } \\
\text { penetration }\end{array}$ \\
\hline Moisture Absorp. & ASTM draft, Sec. 9 & 1 gram (per specimen), max. \\
\hline Moisture Content & ASTM draft, Sec. 8 & $0.5 \%$ by mass, $\max$. \\
\hline \multirow[t]{2}{*}{ Pliability } & a) ASTM draft, Sec. 11 & $\begin{array}{l}\text { no cracking at temperatures of } \\
\text { application }\end{array}$ \\
\hline & $\begin{array}{l}\text { b) UEAtc No. } 27 \\
\text { Sec. } 5.4 .3 \text {. }\end{array}$ & $\begin{array}{l}\text { no cracking or tearing when } \\
\text { urolled at } 32^{\circ} \mathrm{F}\left(0^{\circ} \mathrm{C}\right)\end{array}$ \\
\hline Strain Energy & ASTM draft, Sec. 6 & Irot less than $3 \mathrm{lbf} \cdot \mathrm{in} / \mathrm{in}^{2}\left(0.5 \mathrm{kN} \cdot \mathrm{m} / \mathrm{m}^{2}\right)$ \\
\hline Uplirt & ASTM, UL or FM test & conform to applicable code \\
\hline Weather Resist. Heat Exposure & ASTM draft, Sec. 12 & $\begin{array}{l}15 \% \text { max. change of load-elongation; } \\
\text { low-temperature lexibility not to } \\
\text { exceed } 32^{\circ} \mathrm{F}\left(0^{\circ} \mathrm{C}\right) \text {; strain energy not } \\
\text { less than } 3 \mathrm{lbt} \cdot \mathrm{in} / \mathrm{in}^{2}\left(0.5 \mathrm{kN} \cdot \mathrm{m} / \mathrm{m}^{2}\right) \text {. }\end{array}$ \\
\hline
\end{tabular}


In addition to the criteria in table 7 , other membrane requirements were listed for future development of criteria, but criteria were not suggested at the present. The criteria needed for future development were provided in performance criteria format to indicate the gaps in the knowledge base. Table 8 lists the membrane requirements for which criteria were not proposed. Lack of an acceptable database in the existing standards precluded suggesting completed criteria for these requirements at this time. Nevertheless, it was considered beneficial to present the needed criteria as a first step toward directing future research for standards development concerning the modified bitumens.

In concluding the study, it is recommended that:

1) the criteria in table 7 be incorporated into guide specifications developed by DOD for use of modified bitumens, and

2) research continue to address completion of the proposed criteria given in table 8.

Table 8. Summary of modified bitumens for which criteria have not been proposed

\begin{tabular}{lll}
\hline \hline \multicolumn{1}{c}{ Requirement } & Test Method & Criterion \\
\hline Cyclic Movement & UEAtc No. 27 & $\begin{array}{l}\text { no tears, cracks, or wrinkles: } \\
\text { no total loss of adhesion }\end{array}$ \\
Durability, Granules & ASTM draft, Sec. 15 & not established \\
Durability, Foils & CGSB, Sec. 7.2.6 & not established \\
Puncture, (static) & UEAtc No. 27, Sec. 5.1.9 & not established \\
Puncture, (dynamic) & French Std., NF P 84-353 & not established \\
Seam Strength & not established & not established \\
Slippage of Base Flashing & ASTM draft, Sec. 15 & not established \\
Tear Resistance & not established & not established \\
Water Transmission & not established & the membrane shall be \\
& & watertight as tested \\
Weathering (UV) & not established & not established \\
Weathering (moisture) & not established & not established \\
Weathering (chemical) & not established & not established \\
Weathering (fungus) & not established & not established
\end{tabular}

Although a criterion is proposed for this requirement, a database is lacking at this time for implementation of the suggested criterion.

\section{ACKNOWLEDGMENTS}

This investigation was conducted under the Tri-Service Building Materials Investigational Program. It was jointly sponsored by the Headquarters, U.S. Army Corps of Engineers (COE); U.S. Navy, Naval Facilities (NAVFAC) Engineering Command; and Headquarters, U.S. Air Force, Engineering Division. The encouragement and support of Rodger Seeman (COE) and James Long (NAVFAC) were greatly appreciated. The authors also acknowledge with thanks the assistance of their NIST colleagues who provided reviews of a draft of this report: G. Frohnsdorff, L. Masters, R. Mathey, and M. McKnight. Thanks are also expressed to R. Alumbaugh, Naval Civil Engineering Laboratory (NCEL), Port Hueneme, CA for his review of a draft of the report.

During the study, NIST research staff requested assistance from members of industry associations active in the development of standards for modified-bitumens. Special thanks are extended to these individuals for their valuable contributions in commenting on the plan proposed for conducting the study and/or for providing comments on a draft of this report. These individuals (and the organization represented) are:

Gaylon Baumgardner (ASTM/SPRI)

Kent Blanchard (ASTM)

Peter Colarusso (ASTM)

William Cullen (NRCA)

Helene Hardy Pierce (ASTM)
Thomas Murray (ASTM)

David Richards (ASTM)

Eugene Scott (ARMA)

Pino Vidozzi (ARMA)

Steven Wing (ARMA) 


\section{REFERENCES}

[1] Johnson, Ray, "History and Development of Modiffed Bitumen," Proceedings, 8th NBS/NRCA Conference on Roofing Technology, National Roofing Contractors Association, Rosemont, IL (1987), pp. 81-84.

[2] Meynard, Jean-Yves, "Modified Bitumens: What to Look For," in "The Single-Ply Roofing Membrane," National Roofing Contractors Association, Rosemont, IL (1983), pp. 14-16.

[3] Dupuis, R.M., "Test Results and Trends for EPDMs and Modified Bitumens," 1986 Handbook of Commercial Roofing Systems, HBJ Publications, Cleveland, OH (1986), pp. 11-12.

[4] Porcher, Joel P., Jr., “Advantages, Limitations, and Selection of Modified Bitumen,” Proceedings, 8th NBS/NRCA Conference on Roofing Technology, National Roofing Contractors Association, Rosemont, IL (1987), pp. 75-80.

[5] Liftig, Deborah Currier, "Modified Bitumen Growth Expected," Contractors Guide, Vol. 9, No. 12 (December 1986), pp. 26-29.

[6] Rossiter, Walter J., Jr., "Single-Ply Roofing-A Decade of Change," ASTM Standardization News, Vol. 13, No. 9 (September 1985), pp. 32-35.

[7] Cullen, William, "Project Pinpoint Finds Single-Plies Dominating," The Roofing Spec, (August 1987), pp. 19-20.

[8] Roofing Materials Guide, Vol. 11, (August 1987), National Roofing Contractors Association, Rosemont, IL.

[9] Baxter, Richard P., "Field Performance of Polymer-Modified Bituminous Roofing Membranes," Proceedings, 8th NBS/NRCA Conference on Roofing Technology, National Roofing Contractors Association, Rosemont, IL (1987), pp. 85-90.

[10] "Elastomeric, Thermoplastic, and Modified Bitumen Roofing," A Technical Report of CIB W.83 and RILEM 75-SLR Joint Committee, Materials and Structures, Vol. 19, No. 112 (July/August 1986), pp. 323-330.

[11] Rossiter, Walter J., Jr. and Mathey, Robert G., "A Methodology for Developing Tests to Aid Service-Life Prediction of Single-Ply Roofing Membranes," Proceedings, 7th NBS/NRCA Conference on Roofing Technology, National Roofing Contractors Association, Rosemont, IL (1983), pp. 4-11.

[12] Mathey, Robert G. and Cullen, William C., "Preliminary Performance Criteria for Bituminous Membrane Roofing," National Bureau of Standards (U.S.), Building Science Series 55 (November 1974), 12 pages.

[13] European Union of Agrément, "General Directive for the Assessment of Roof Waterproofing Systems," M.O.A.T. No. 27: 1983, (January 1983), Paris.

[14] European Union of Agrément, "Special Directives for the Assessment of Reinforced Homogeneous Waterproofing Coverings of Styrene-Butadiene-Styrene (SBS) Elastomer Bitumen," M.O.A.T. No. 31: 1984, (August 1984), Paris.

[15] European Union of Agrement, "Special Directives for the Assessment of Reinforced Waterproofing Coverings of Atactic Polypropylene (APP) Polymer Bitumen," M.O.A.T. No. 32: 1984, (August 1984), Paris.

[16] "Recommended Performance Criteria for Modified Bitumen Roof Membrane Systems," Technical Document MB-30, Midwest Roofing Contractors Association, Kansas City, MO (1983).

[17] "Standard for Membrane, Modified, Bituminous, Prefabricated, and Reinforced for Roofing," Canadian General Standards Board, 37-GP-56M (July 1980).

[18] ASTM Draft, "Standard Test Methods for Sampling and Testing Modified Bituminous Sheet Materials Used in Roofing and Waterproofing," under ASTM Committee D08, Subcommittee D08.04 review (November 1987).

[19] Frohnsdorff, Geoffrey, Brown, Paul W., and Pielert, James H., "Standard Specifications for Cements and the Role in Their Development of Quality Assurance Systems for Laboratories," Proceedings, 8th International Conference on the Chemistry of Cement, Rio de Janeiro, Vol. VI (22-27 September 1986) pp. 316-320.

[20] Cullen, W.C., "A Performance Approach to Quality Roofing Membranes," Materials and Structures, Vol. 17, No. 100 (July-August 1984), pp. 333-338.

[21] Cramp, A.P., Cullen, W.C., and Tryon, M., "Slippage of Built-Up Roof Membranes: Causes and Prevention," NBS Report 10950 (November 1972), 90 pages.

[22] ASTM D 1079, Standard Definition of Terms Relating To Roofing, Waterproofing, and Bituminous Materials," Annual Book of ASTM Standards, Vol. 04.04, ASTM, Philadelphia, PA (1986).

[23] Koontz, Jim D., “A Comparative Study of Dynamic Impact and Static Loading of One-Ply Roofing Assemblies," in Roofing Research and Standards Development, ASTM STP 959, Critchell, R.A., Ed., ASTM, Philadelphia, PA (1987), Pp. 23-52.

[24] Rossiter, Walter J., Jr. and Bentz, Dale P., "Strain Energy of Bituminous Built-Up Membranes: An Alternative to the Tensile Strength Criterion," National Bureau of Standards (U.S.), NBSIR 86-3418 (September 1986), 67 pages.

[25] Busching, Herbert W., Mathey, Robert G., Rossiter, Walter J., Jr., and Cullen, William C., "Effects of Moisture in Built-Up Roofing: A State-of-the-Art Literature Survey," National Bureau of Standards (U.S.), Technical Note 965 (July 1978), 78 pages.

[26] Lee, Jun W. and Dupuis, Rene M., “A Performance Evaluation of Modified Bitumen Roof Membranes Using the Strain Energy Approach," Research Report, Structural Research, Inc., Madison, WI (January 1987), 99 pages.

[27] Wells, James R., "Strain Energy as a Membrane Performance Measure," Proceedings, Mathematical Modeling of Roofing Systems, Oak Ridge National Laboratory (15 September 1988), 8 pages.

[28] Marechal, J.C., "Methods for the Study of Aging of Bitumen-Polymer SBS Materials," Proceedings, 2nd International Conference on the Durability of Building Materials and Components, National Bureau of Standards, Gaithersburg, MD (14-16 September 1981), pp. 452-462.

[29] Rossiter, Walter J., Jr., "The Effect of Application Parameters on Adhesive-Bonded Seams in Single-Ply Membranes," Proceedings, 2nd International Symposium on Roofing Technology, National Roofing Contractors Association, Rosemont, IL (September 1985), pp. 383-390.

[30] Rossiter, Walter J., Jr. and Bentz, Dale P., ibid., p. 27. 


\section{APPENDIX A. PRELIMINARY DATA ON TYPICAL POLYMER- MODIFIED BITUMINOUS ROOFING MEMBRANE MATERIALS}

\section{A.1 INTRODUCTION}

During this study, limited laboratory testing was conducted on five typical modified bitumens that were commercially available in the U.S. roofing industry. The five products are described in table A1. As is evident, two of the membrane samples were APP-modified, and two were SBS-modified. The fifth sample was a self-adhering membrane material that had an SBS-type modifier.

The tests were conducted to compare the proposed interim criteria with properties of typical commercially-available modified membrane samples. Because the scope of the study was to suggest criteria for selecting polymer-modified bitumens based on a review of existing standards and related documents, the testing conducted on the membrane samples was limited. For example, load-elongation tests were only conducted on the sheets in their transverse (or cross-machine) direction.

Table A1. Modified bitumen samples included in the study

\begin{tabular}{cl}
\hline Sample No. & \multicolumn{1}{c}{ Membrane Material } \\
\hline 1. & Atactic-propylene (APP) modified; no surfacing \\
2. & Atactic-propylene (APP) modified; no surfacing \\
3. & Styrene-butadiene-styrene (SBS) modified; \\
& surfacing consisting of white granules \\
4. & Styrene-butadiene-styrene (SBS) modified; no surfacing; this sheet \\
& is only used as a base ply in a 2-ply membrane \\
5. & Styrene-butadiene-styrene (SBS) modified; self-adhering material \\
& with a surfacing consisting of a white polymeric film \\
\hline
\end{tabular}

This Appendix presents the results of the limited tests (tables A2-A13). The membrane characteristics examined were thickness, tensile strength, tensile elongation, low-temperature flexibility, tear resistance, dimensional stability, moisture content, and strain energy. Each of these tests was conducted according to the method cited in table 7 of the main body of the report. The data were used in support of the prescriptive criteria suggested in table 7. In addition, heat and UV exposure tests were conducted according to the proposed ASTM methods. 


\section{A.2 RESULTS}

\section{A.2.1 Thickness}

The results of the thickness are given in table A2. The membrane materials ranged from as thin as 0.04 in $(1 \mathrm{~mm})$ to as thick as 0.16 in $(4 \mathrm{~mm})$. For any specimen, the variation in measured thickness did not exceed 4 percent. This reflects the automatic control that modern roofing plants use to monitor and adjust the thickness of the factory-fabricated membrane material. Based on these results, it is suggested in the criteria (table 6) that the average thickness of a product not be less than 5 percent of the nominal value stated by the manufacturer.

Table A2. Thickness of the test specimens ${ }^{2}$

\begin{tabular}{cccccc}
\hline \hline \multirow{2}{*}{$\begin{array}{c}\text { Sample } \\
\text { No. }\end{array}$} & range & in & av & Thickness & mm \\
\cline { 2 - 6 } & $0.153-0.160$ & 0.157 & $3.89-4.06$ & 3.99 & $\begin{array}{c}\text { COV' } \\
\%\end{array}$ \\
\hline 1. & $0.146-0.156$ & 0.153 & $3.71-3.96$ & 3.89 & 1.7 \\
2. & $0.156-0.158$ & 0.156 & $3.96-4.01$ & 3.97 & 2.7 \\
3. & $0.087-0.093$ & 0.090 & $2.21-2.36$ & 2.28 & 0.6 \\
4. & $0.042-0.046$ & 0.044 & $1.07-1.17$ & 1.12 & 3.5 \\
5. & & & & 4.0 \\
\hline
\end{tabular}

Average of five measurements, ASTM draft, Sec. 5.

b $\mathrm{COV}$ indicates coefficient of variation.

\section{A.2.2 Tensile Strength}

Table $\mathrm{A} 3$ presents the tensile strength (load) results for tests conducted at both $73^{\circ} \mathrm{F}\left(23^{\circ} \mathrm{C}\right)$ and $0^{\circ} \mathrm{F}\left(-18^{\circ} \mathrm{C}\right)$. For these tests, "dog-bone" specimens were used instead of strip specimens as suggested in the ASTM draft [18]. The results indicated that, as was expected [24], the materials were stronger at the lower temperature. At $0^{\circ} \mathrm{F}\left(-18^{\circ} \mathrm{C}\right)$, the strength ranged from 39 to $218 \mathrm{lbf} /$ in $(6.9$ to $38 \mathrm{kN} / \mathrm{m})$. This finding is consistent with published data on the load-elongation properties of the modified bitumens that indicate a wide range of strength $[24,26]$.

Note that most of the samples in table A3 had coefficients of variation of 10 percent or less. For one measurement, the variation was 14 percent. These results were used to support the suggested load criterion that the average value not be less than 15 percent of the nominal value stated by the manufacturer.

Table A3. Tensile strength of the specimens tested at 73 and $0^{\circ} \mathrm{F}\left(23\right.$ and $\left.-18^{\circ} \mathrm{C}\right)$ before laboratory exposure

\begin{tabular}{|c|c|c|c|c|c|}
\hline \multirow{3}{*}{$\begin{array}{c}\text { Sample } \\
\text { No. }\end{array}$} & \multicolumn{4}{|c|}{ Load, mar. } & \multirow{3}{*}{$\mathrm{COV}_{\%}$} \\
\hline & \multicolumn{2}{|c|}{ lbf/in } & \multicolumn{2}{|c|}{$\mathbf{k N} / \mathbf{m m}$} & \\
\hline & range & 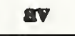 & range & $a v$ & \\
\hline $\begin{array}{ll}0 & 1 . \\
0 & 2 . \\
0 & 3 . \\
d & 3 . \\
\approx & 5 .\end{array}$ & $\begin{array}{r}106-126 \\
54-63 \\
48-58 \\
11-16 \\
56-60\end{array}$ & $\begin{array}{c}113^{c} \\
60 \\
54 \\
14 \\
58\end{array}$ & $\begin{array}{c}19-22 \\
9.4-11 \\
8.4-10 \\
1.9-2.8 \\
9.8-11\end{array}$ & $\begin{array}{l}20^{6} \\
11 \\
9.5 \\
2.3 \\
10\end{array}$ & $\begin{array}{c}8.4 \\
5.4 \\
7.9 \\
14 \\
3.2\end{array}$ \\
\hline $\begin{array}{ll}0 & 1 . \\
0 & 2 . \\
0 & 2 . \\
I & 3 . \\
I & 4 . \\
0 & 5 . \\
0\end{array}$ & $\begin{array}{c}193-240 \\
106-128 \\
70-90 \\
37-42 \\
67-77\end{array}$ & $\begin{array}{r}218 \\
114 \\
80 \\
39 \\
74\end{array}$ & $\begin{array}{cc}34 & -42 \\
19 & -22 \\
12 & -16 \\
6.5 & -7.4 \\
12 & -14\end{array}$ & $\begin{array}{c}38 \\
20 \\
14 \\
6.9 \\
13\end{array}$ & $\begin{array}{c}10 \\
7.4 \\
11 \\
5.2 \\
5.2 \\
\end{array}$ \\
\hline
\end{tabular}

'Average of five measurements (unless otherwise indicated), ASTM draft, Sec. 6; tests conducted on the transverse direction of the sheet.

${ }^{b} \mathrm{COV}$ indicates coefficient of variation.

c Average of four measurements.

- Specimen did not break; test terminated at 50 percent elongation due to lack of space in the cold chamber. 


\section{A.2.3 Elongation}

Table A4 presents the percent elongation results for tests conducted at both room temperature and $0^{\circ} \mathrm{F}\left(-18^{\circ} \mathrm{C}\right)$. For samples 2,3 , and 4 , the elongation decreased as the temperature decreased. Sample 1 showed little variation of elongation for the two test temperatures. This observation was not surprising, as it was noted for a modified bitumen in a previous study [24]. Sample 5 could not be extended to its maximum at $0^{\circ} \mathrm{F}\left(-18^{\circ} \mathrm{C}\right)$ because of lack of extension space in the cold chamber. In this case, specimen elowgation had reached 50 percent, when the test was terminated.

Table A4. Elongation of the specimens under tensile load tested at 73 and $0^{\circ} \mathrm{F}\left(23\right.$ and $\left.-18^{\circ} \mathrm{C}\right)$ before laboratory exposure

\begin{tabular}{|c|c|c|c|c|c|c|}
\hline \multirow{3}{*}{$\begin{array}{c}\text { Sample } \\
\text { No. }\end{array}$} & \multicolumn{5}{|c|}{ Elongation, \% } & \multirow{3}{*}{$\begin{array}{c}\mathrm{COV}^{\circ} \\
\%\end{array}$} \\
\hline & \multicolumn{2}{|c|}{ At Maximum Load } & \multirow{2}{*}{$\begin{array}{c}\mathrm{COV}^{\mathrm{b}} \\
\%\end{array}$} & \multicolumn{2}{|c|}{ At Specimen Break } & \\
\hline & range & av & & range & av & \\
\hline 1 & $---^{c}$ & $---^{c}$ & $--c^{c}$ & $1.8-2.2$ & $2.0^{4}$ & 9.9 \\
\hline 2. & $34-40$ & 37 & 7.1 & $38-46$ & 42 & 9.7 \\
\hline 2] 3. & --- & --- & --- & $33-47$ & 39 & 14 \\
\hline 4. & $1.5-2.6$ & $2.0^{d}$ & 2.2 & $9.1-9.9$ & $9.6^{d}$ & 3.8 \\
\hline$\approx 5$. & $97-177$ & 139 & 29 & $136-177$ & 157 & 12 \\
\hline of 1 & --- & --- & --- & $1.9-3.1$ & 2.3 & 23 \\
\hline$\infty$ & $6.6-12$ & 8.0 & 42 & $7.9-14$ & 12 & 22 \\
\hline 13. & --- & --- & --- & $20-34$ & 29 & 19 \\
\hline$\underbrace{-}_{1} 4$. & --- & --- & --- & $1.8-2.7$ & 2.2 & 17 \\
\hline$\therefore 5$. & --- & --- & --- & $\mathrm{NA}^{\circ}$ & $50^{\prime}$ & $\mathrm{NA}^{\circ}$ \\
\hline
\end{tabular}

Average of five measurements (unless otherwise indicated), ASTM draft, Sec. 6; tests conducted on the transverse direction of the sheet.

${ }^{b} \mathrm{COV}$ indicates coefficient of variation.

c The dash lines indicate that the maximum load occurred essentially (within 10\%) at the end of the test.

Average of four measurements.

- Not applicable; specimen did not break; test terminated at 50 percent elongation due to lack of space in the cold chamber.

${ }^{1}$ All tests terminated at 50 percent elongation.

As is evident from table A4, depending on the temperature, the elongations of the five samples varied considerably, ranging from about 2 percent (Samples 2 and 4) to over 150 percent (Sample 5) at break. The greatest coefficient of variation was 23 percent. Consistent with this finding, it was suggested (table 6) that the average measured elongation not be less than 20 percent of the nominal value stated by the manufacturer.

\section{A.2.4 Low-Temperature Flexibility}

The values of low-temperature flexibility determined for the test samples are given in table A5. They ranged from $23^{\circ} \mathrm{F}\left(-5^{\circ} \mathrm{C}\right)$ to less than $-30^{\circ} \mathrm{F}\left(-34^{\circ} \mathrm{C}\right)$. The APP-modified samples (Nos. 1 and 2) had higher values than the SBS-modified samples (Nos. 3-5). The results were consistent with literature citations that low-temperature flexibility points of APP and SBS materials are normally less than $25^{\circ} \mathrm{F}\left(-4^{\circ} \mathrm{C}\right)$ and $5^{\circ} \mathrm{F}\left(-15^{\circ} \mathrm{C}\right)$, respectively.

Table A5. Low-temperature flexibility of the test specimens before laboratory exposure

\begin{tabular}{ccc}
\hline $\begin{array}{c}\text { Sample } \\
\text { No. }\end{array}$ & $\begin{array}{c}\text { Lowest Temperature at Which Cracling Did Not Occar } \\
{ }^{\circ} \mathrm{C}\end{array}$ \\
\hline 1. & 23 & -5 \\
2. & 8 & -13 \\
3. & -2 & -19 \\
4. & -23 & -30 \\
5. & $<-30^{\mathrm{b}}$ & $<-34^{\circ}$ \\
\hline
\end{tabular}

'Test of five specimens, ASTM draft, Sec. 11; the low-temperature flexibility value was that temperature at which none of the five specimens cracked.

b Test was not conducted below this temperature. 


\section{A.2.5 Tear Resistance}

The results of the tear resistance tests are given in table A6. As was the case for tensile strength, the maximum tear load showed a wide variation between the five materials, ranging from 32 to 144 lbf $(142$ to $639 \mathrm{~N})$. The maximum coefficient of variation (19\%) was observed for Sample 4; the remaining 4 samples had coefficients of variation of 10 percent or less. The suggested criterion (table 6) is that the average tear resistance not be less than 20 percent of the stated nominal value.

Table A6. Tear resistance of the test specimens ${ }^{2}$

\begin{tabular}{ccccccc}
\hline \hline & \multicolumn{7}{c}{ Load, max. } \\
\cline { 2 - 7 } $\begin{array}{c}\text { Sample } \\
\text { No. }\end{array}$ & range & lbf & av & range & av & $\begin{array}{c}\text { COV } \\
\%\end{array}$ \\
\hline 1. & $131-168$ & 144 & $584-746$ & 639 & 10 \\
2. & $92-104$ & 96 & $407-460$ & 428 & 5 \\
3. & $82-98$ & 87 & $365-436$ & 386 & 8 \\
4. & $24-41$ & 32 & $108-184$ & 142 & 19 \\
5. & $72-78$ & 76 & $320-349$ & 338 & 4 \\
\hline
\end{tabular}

${ }^{a}$ Average of five specimens, ASTM draft, Sec. 7.

\section{A.2.6 Dimensional Stability}

When heated at $176^{\circ} \mathrm{F}\left(80^{\circ} \mathrm{C}\right)$ for 24 hours, the test samples generally showed little dimensional change (table A7). Specifically, Samples 2 and 5 exhibited a change in the length (longitudinal direction of sheet) of 1 percent, but no change in width. The other three samples had no measurable dimensional change. Note that the data for this characteristic are limited, having been conducted only on one specimen of each sample. Nevertheless, the results are consistent with the suggested criterion that the dimensional change on heating not exceed 1 percent (table 7).

Table A7. Dimensional stability of the test specimens

\begin{tabular}{ccc}
\hline $\begin{array}{c}\text { Sample } \\
\text { No. }\end{array}$ & length & Dimensional Change, \% \\
\hline 1. & 0 & width \\
\hline 2. & 1 & 0 \\
3. & 0 & 0 \\
4. & 0 & 0 \\
5. & 1 & 0 \\
\hline
\end{tabular}

a Average of five measurements on one specimen, ASTM draft, Sec, 10.

b The variation was negligible for the tests conducted, and is not reported. 


\section{A.2.7 Moisture Content}

Moisture contents for the five samples were found to be 0.3 percent by mass or less (table A8). Only one determination was made for each membrane sample. The limited data are consistent with the suggested criterion that moisture content not be greater than 0.5 percent by mass (table 7 ).

Table A8. Moisture content of the test specimens"

\begin{tabular}{cc}
\hline \hline $\begin{array}{c}\text { Sample } \\
\text { No. }\end{array}$ & Molsture Content by Mass, \%० \\
\hline 1. & 0 \\
2. & 0.3 \\
3. & 0.1 \\
4. & 0.2 \\
5. & 0 \\
\hline
\end{tabular}

One measurement only per specimen, ASTM draft, Sec. 8.

\section{A.2.8 Strain Energy}

The results of the strain energy determinations at both room temperature and $0{ }^{\circ} \mathrm{F}\left(-18^{\circ} \mathrm{C}\right)$ are given in table A9. The suggested criterion for strain energy is that it not be less than $3 \mathrm{lbf} \cdot \mathrm{in} / \mathrm{in}^{2}(0.5$ $\left.\mathrm{kN} \cdot \mathrm{m} / \mathrm{m}^{2}\right)$ when the membrane material is tested at $0^{\circ} \mathrm{F}\left(-18^{\circ} \mathrm{C}\right)$ in its weaker direction. This criterion value was selected based on recommendations for bituminous built-up membranes [24]. The value for the criterion was also the minimum suggested in the MRCA performance criteria for modified bitumens [16].

Table A9. Strain energy per unit gage length of the specimens tested at 73 and $0^{\circ} \mathrm{F}$ ( 23 and $-18^{\circ} \mathrm{C}$ ) before laboratory exposure

\begin{tabular}{|c|c|c|c|c|c|c|}
\hline \multirow{3}{*}{$\begin{array}{c}\text { Sample } \\
\text { No. }\end{array}$} & \multicolumn{6}{|c|}{ Strain Energy, lbein $/ \mathrm{in}^{2}\left(\mathrm{~N} \cdot \mathrm{m} / \mathrm{mr}^{2}\right)$} \\
\hline & \multicolumn{2}{|c|}{ At Maximum Load } & \multirow{2}{*}{$\begin{array}{c}\mathrm{COV}^{\circ} \\
\%\end{array}$} & \multicolumn{2}{|c|}{ At Specimen Break } & \multirow{2}{*}{$\begin{array}{c}\mathrm{COV} \\
\%\end{array}$} \\
\hline & range & av & & range & av & \\
\hline 1. & $---^{\circ}$ & $---^{6}$ & $---^{c}$ & $\begin{array}{l}1.1-1.5 \\
(0.19-0.26)\end{array}$ & $\begin{array}{c}1.3 \\
(0.23)\end{array}$ & 14 \\
\hline $0^{2 .}$ & $\begin{array}{l}15-21 \\
(2.6-3.7)\end{array}$ & $\begin{array}{l}18 \\
(3.2)\end{array}$ & 13 & $\begin{array}{ll}17 & -25 \\
(3.0-4.4)\end{array}$ & $\begin{array}{l}21 \\
(3.7)\end{array}$ & 15 \\
\hline $\int_{0}^{2} 3$. & --- & --- & --- & $\begin{array}{l}11-19 \\
(1.9-3.3)\end{array}$ & $\begin{array}{l}15 \\
(2.6)\end{array}$ & 20 \\
\hline is 4. & $\begin{array}{c}0.16-0.26 \\
(0.03-0.05)\end{array}$ & $\begin{array}{c}0.21^{d} \\
(0.04)\end{array}$ & 21 & $\begin{array}{c}0.89-1.1 \\
(0.16-0.19)\end{array}$ & $\begin{array}{r}0.984 \\
(0.17)\end{array}$ & 9.0 \\
\hline 5. & $\begin{array}{ll}41 & -87 \\
(7.2 & -15)\end{array}$ & $\begin{array}{c}67 \\
(12) \\
\end{array}$ & 34 & $\begin{array}{cc}63 & -87 \\
(11 & -15) \\
\end{array}$ & $\begin{array}{c}76 \\
(13)\end{array}$ & 15 \\
\hline 1. & --- & --- & --- & $\begin{array}{l}2.2-4.6 \\
(0.39-0.81)\end{array}$ & $\begin{array}{l}3.0 \\
(0.53)\end{array}$ & 36 \\
\hline $0^{2 .}$ & $\begin{array}{l}2.9-12 \\
(0.51-2.1)\end{array}$ & $\begin{array}{l}7.5 \\
(1.3)\end{array}$ & 44 & $\begin{array}{c}8.3-14 \\
(1.5-2.5)\end{array}$ & $\begin{array}{l}11 \\
(1.9)\end{array}$ & 23 \\
\hline $\begin{array}{ll}\infty & \\
I & \end{array}$. & -- & --- & -- & $\begin{array}{ll}11 & -29 \\
(1.9-5.1)\end{array}$ & $\begin{array}{l}18 \\
(3.2)\end{array}$ & 27 \\
\hline$\stackrel{5}{1}_{0}^{5} 4$. & -- & --- & -- & $\begin{array}{c}0.42-0.64 \\
(0.07-0.11)\end{array}$ & $\begin{array}{c}0.55 \\
(0.10)\end{array}$ & 18 \\
\hline 5. & --- & --- & --- & $\begin{array}{ll}28 & -32 \\
(4.9 & -5.6)\end{array}$ & $\begin{array}{l}30^{\circ} \\
(5.3)\end{array}$ & 1.1 \\
\hline
\end{tabular}

- Average of five measurements (unless otherwise indicated), ASTM draft, Sec. 6; tests conducted on the transverse direction of the sheet.

${ }^{b} \mathrm{COV}$ indicates coefficient of variation.

c The dash lines indicate that the maximum load occurred essentially (within 10\%) at the end of the test.

Average of four measurements.

- Specimen did not break; test terminated at 50 percent elongation due to lack of space in the cold chamber. 
The data in table A9 indicate that four samples (Nos. 1-3,5) have values of strain energy that meet or exceed the suggested minimum. Sample 4 has a strain energy at $0^{\circ} \mathrm{F}\left(-18^{\circ} \mathrm{C}\right)$ which is less than the suggested criterion. This product is normally used in service in conjunction with another ply of modified bitumen, and for this reason, should be tested as a composite membrane material.

\section{A.2.9 Heat and UV Exposure Tests}

The results of the heat and UV exposure tests, conducted according to the procedure given in the ASTM draft [18], are presented in tables A10-A13, and illustrated in figures A1-A4. Although the results varied for the different membrane materials, in many cases, only slight changes $(<15 \%)$ in the materials' tensile strength, elongation, low-temperature flexibility, and strain energy were found as compared to those property values for the unexposed samples.

Some of the major changes noted for each material are as follows:

Sample 1: a decrease of 20 percent in tensile strength due to UV exposure an increase in low-temperature flexibility from $23^{\circ} \mathrm{F}\left(-5^{\circ} \mathrm{C}\right)$ to slightly less than $40^{\circ} \mathrm{F}\left(4^{\circ} \mathrm{C}\right)$ upon heat and UV exposure

Sample 2: $\quad$ a decrease in elongation of about 60 percent due to heat and UV exposure, which accounted for a decrease in total strain energy of about 68 percent

an increase in low-temperature flexibility from $8^{\circ} \mathrm{F}\left(-13^{\circ} \mathrm{C}\right)$ to $24^{\circ} \mathrm{F}\left(-4^{\circ} \mathrm{C}\right)$ due to heat exposure; this test could not be conducted on the UV-exposed specimens because the exposure resulted in cracking of the specimen surface

Sample 3: $\quad$ an increase in tensile strength of about 40 percent and a drop in elongation of about 28 percent due to UV exposure; the result was the effect on strain energy was a slight increase

Sample 4: $\quad$ an increase in low-temperature flexibility from $-23^{\circ} \mathrm{F}\left(-31^{\circ} \mathrm{C}\right)$ to $32^{\circ} \mathrm{F}\left(0^{\circ} \mathrm{C}\right)$ upon UV exposure

Sample 5: changes in elongation could not be determined because the sample could not be extended beyond 50 percent in the cold chamber used during the tests

a decrease in tensile strength of about 49 percent due to heat exposure; this resulted in a comparable decrease in total strain energy

Table A10. Tensile strength of the specimens tested at $0^{\circ} \mathrm{F}\left(-18^{\circ} \mathrm{C}\right)$ after laboratory exposure

\begin{tabular}{|c|c|c|c|c|c|}
\hline \multirow{3}{*}{$\begin{array}{c}\text { Sample } \\
\text { No. }\end{array}$} & \multicolumn{4}{|c|}{ Load, max } & \multirow{3}{*}{$\begin{array}{c}\mathrm{COV}^{\mathrm{b}} \\
\%\end{array}$} \\
\hline & \multicolumn{2}{|c|}{$\mathrm{lbf} / \mathrm{in}$} & \multicolumn{2}{|c|}{$\mathbf{k N} / \mathbf{m}$} & \\
\hline & range & $\mathrm{av}$ & range & $\operatorname{av}$ & \\
\hline 1. & $210-245$ & 231 & $37-43$ & 41 & 6.4 \\
\hline 2. & $113-126$ & 119 & $20-22$ & 21 & 3.9 \\
\hline 苞 3. & 82- 91 & 88 & $14-16$ & 15 & 5.0 \\
\hline 4. & $42-47$ & 45 & $7.4-8.2$ & 7.9 & 4.0 \\
\hline $5 .^{c}$ & $37-39$ & 38 & $6.5-6.8$ & 6.7 & 2.1 \\
\hline \multirow{5}{*}{$\begin{array}{l}1 . \\
2 . \\
3 . \\
4 . \\
5 .\end{array}$} & $155-192$ & 173 & $27-34$ & 30 & 10 \\
\hline & $87-99$ & 93 & $\begin{array}{ll}15 & -17\end{array}$ & 16 & 5.2 \\
\hline & $101-136$ & 114 & $18-24$ & 20 & 11 \\
\hline & $38-42$ & 41 & $6.7-7.4$ & 7.2 & 3.9 \\
\hline & $57-76$ & 69 & $10-13$ & 12 & 11 \\
\hline
\end{tabular}

Average of five measurements, ASTM draft, Sec. 5.

- COV indicates coefficient of variation.

'Specimen did not break; test terminated at 50 percent elongation due to lack of space in the cold chambaer. 
Table A11. Elongation of the specimens under tensile load tested at $0^{\circ} \mathrm{F}\left(-18^{\circ} \mathrm{C}\right)$ after laboratory exposure

\begin{tabular}{|c|c|c|c|c|c|c|}
\hline \multirow{3}{*}{$\begin{array}{c}\text { Sample } \\
\text { No. }\end{array}$} & \multicolumn{6}{|c|}{ Elongation, \% } \\
\hline & \multicolumn{2}{|c|}{ At Maximum Load } & \multirow{2}{*}{$\begin{array}{c}\text { Cov' } \\
\%\end{array}$} & \multicolumn{2}{|c|}{ At Specimen Break } & \multirow{2}{*}{$\begin{array}{c}\text { Cor } \\
\%\end{array}$} \\
\hline & range & av & & range & ar & \\
\hline \multirow{5}{*}{ 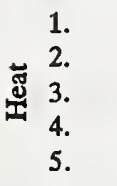 } & $---^{e}$ & $--c^{c}$ & $---^{c}$ & $2.0-2.6$ & 2.4 & 9.0 \\
\hline & $3.0-3.5$ & 3.4 & 5.7 & $4.0-4.2$ & 4.1 & 2.0 \\
\hline & --- & --- & --- & $22-30$ & 26 & 13 \\
\hline & --- & --- & --- & $1.9-2.6$ & 2.4 & 12 \\
\hline & --- & --- & --- & $N^{d}$ & $50^{\circ}$ & $N^{d}$ \\
\hline \multirow{5}{*}{ \ $\begin{array}{l}1 . \\
3 . \\
4 . \\
5 !\end{array}$} & --- & --- & -- & $1.2-3.0$ & 2.1 & 32 \\
\hline & $1.8-2.2$ & 2.1 & 9.3 & $3.6-5.9$ & 4.7 & 23 \\
\hline & --- & --- & --- & $11-26$ & 21 & 28 \\
\hline & --- & --- & --- & $1.3-3.3$ & 2.7 & 30 \\
\hline & --- & --- & --- & $N^{d}$ & $50^{\circ}$ & $\mathrm{NA}^{\mathrm{d}}$ \\
\hline
\end{tabular}

Average of five measurements (unless otherwise indicated), ASTM draft, Sec. 6; tests conducted on the transverse direction of the sheet.

bOV indicates coefficient of variation.

'The dash lines indicate that the maximum load occurred essentially (within 10\%) at the end of the test.

dNot applicable; specimen did not break; test terminated at 50 percent elongation due to lack of space in the cold chamber.

- All tests terminated at 50 percent elongation.

'Average of four measurements.

Table A12. Low-temperature flexibility of the test specimens after laboratory exposure"

\begin{tabular}{|c|c|c|}
\hline \multirow{2}{*}{$\begin{array}{c}\text { Sample } \\
\text { No. }\end{array}$} & \multicolumn{2}{|c|}{ Lowest Temperature at Which Cracking Did Not Occur } \\
\hline & & \\
\hline 1. & 39 & 4 \\
\hline 2. & 24 & -4 \\
\hline 3. & 2 & -17 \\
\hline 4. & -23 & -31 \\
\hline 5. & $<-30^{b}$ & $<-34^{b}$ \\
\hline \multirow{5}{*}{$\begin{array}{l}1 . \\
2 . \\
3 . \\
4 . \\
5 .\end{array}$} & 38 & 3 \\
\hline & $--^{c}$ & $--^{c}$ \\
\hline & -2 & -19 \\
\hline & 32 & 0 \\
\hline & $<-30^{b}$ & $<-34^{b}$ \\
\hline
\end{tabular}

"Test of five specimens, ASTM draft, Sec. 11.

- Test was not conducted below this temperature.

' Specimens were severely cracked on the surface after the UV exposure and consequently could not be tested by a procedure that has cracking has the test criterion. 
Table A13. Strain energy per unit gage length of the specimens tested at $0^{\circ} \mathrm{F}\left(-18^{\circ} \mathrm{C}\right)$ after laboratory exposure

\begin{tabular}{|c|c|c|c|c|c|c|}
\hline \multirow{3}{*}{$\begin{array}{c}\text { Sample } \\
\text { No. }\end{array}$} & \multicolumn{6}{|c|}{ Strain Energt, lbe:in/in $\left(\mathrm{N} \cdot \mathrm{m} / \mathrm{m}^{2}\right)$} \\
\hline & \multicolumn{2}{|c|}{ At Maximum Load } & \multirow{2}{*}{$\begin{array}{c}\text { COVt } \\
\%\end{array}$} & \multicolumn{2}{|c|}{ At Specimen Break } & \multirow{2}{*}{$\begin{array}{c}\text { COV } \\
\%\end{array}$} \\
\hline & range & $\mathbf{a v}$ & & range & $\mathbf{a v}$ & \\
\hline 1. & $---^{c}$ & $--c^{e}$ & $---^{c}$ & $\begin{array}{c}2.4-3.9 \\
(0.42-0.68)\end{array}$ & $\begin{array}{c}3.2 \\
(0.56)\end{array}$ & 17 \\
\hline 2. & $\begin{array}{c}2.7-3.3 \\
(0.47-0.58)\end{array}$ & $\begin{array}{c}3.1 \\
(0.54)\end{array}$ & 8.0 & $\begin{array}{c}3.5-3.9 \\
(0.61-0.68)\end{array}$ & $\begin{array}{c}3.7 \\
(0.65)\end{array}$ & 4.3 \\
\hline 苟 3. & --- & --- & --- & $\begin{array}{c}16-22 \\
(2.8-3.9)\end{array}$ & $\begin{array}{l}19 \\
(3.3)\end{array}$ & 16 \\
\hline 4. & --- & --- & --- & $\begin{array}{c}0.54-0.86 \\
(0.09-0.15)\end{array}$ & $\begin{array}{c}0.74 \\
(0.13)\end{array}$ & 17 \\
\hline 5. & --- & --- & --- & $\begin{array}{c}16-17 \\
(2.8-3.0)\end{array}$ & $\begin{array}{r}16^{d} \\
(2.8)\end{array}$ & 2.3 \\
\hline 1. & --- & --- & --- & $\begin{array}{c}1.0-3.4 \\
(0.18-0.60)\end{array}$ & $\begin{array}{c}2.4 \\
(0.42)\end{array}$ & 38 \\
\hline 2. & $\begin{array}{c}1.0-1.5 \\
(0.18-0.26)\end{array}$ & $\begin{array}{c}1.3 \\
(0.23)\end{array}$ & 17 & $\begin{array}{c}2.4-4.6 \\
(0.42-0.81)\end{array}$ & $\begin{array}{c}3.4 \\
(0.60)\end{array}$ & 28 \\
\hline $3^{3 .}$ & -- & -- & --- & $\begin{array}{c}10-28 \\
(1.8-4.9)\end{array}$ & $\begin{array}{l}20 \\
(3.5)\end{array}$ & 34 \\
\hline 4. & --- & --- & -- & $\begin{array}{c}0.33-1.0 \\
(0.06-0.18)\end{array}$ & $\begin{array}{c}0.77 \\
(0.13)\end{array}$ & 34 \\
\hline $5:^{\circ}$ & --- & -- & -- & $\begin{array}{c}27-31 \\
(4.7-5.4)\end{array}$ & $\begin{array}{r}29^{d} \\
(5.1)\end{array}$ & 6.5 \\
\hline
\end{tabular}

"Average of five measurements (unless otherwise indicated), ASTM draft, Sec. 6; tests conducted on the transverse direction of the sheet.

b COV indicates coefficient of variation.

'The dash lines indicate that the maximum load occurred essentially (within 10\%) at the end of the test, and the strain energy was taken only as that at break.

d Specimen did not break; test terminated at 50 percent elongation due to lack of space in the cold chamber.

- Average of four measurements. 


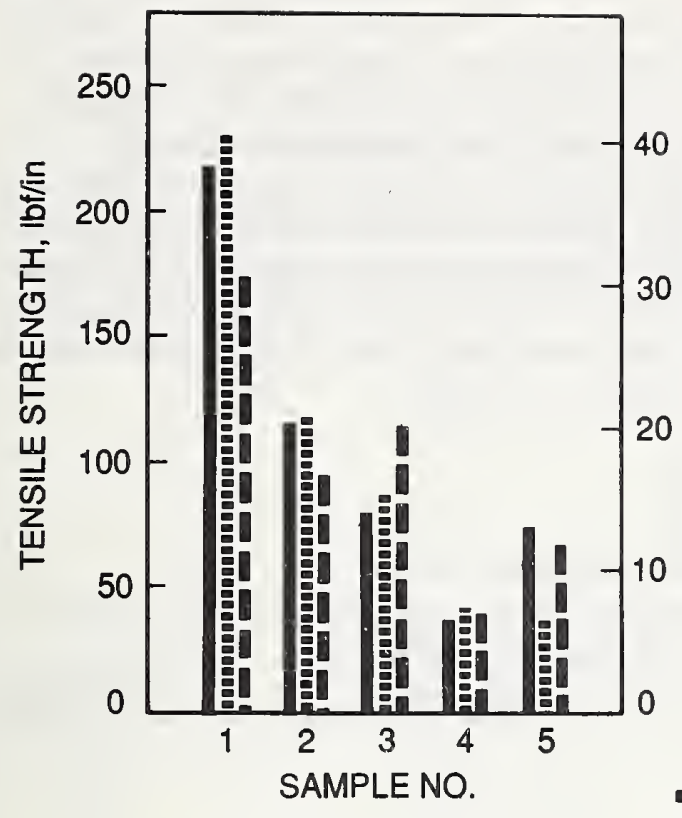

Figure A1. Tensile strength results

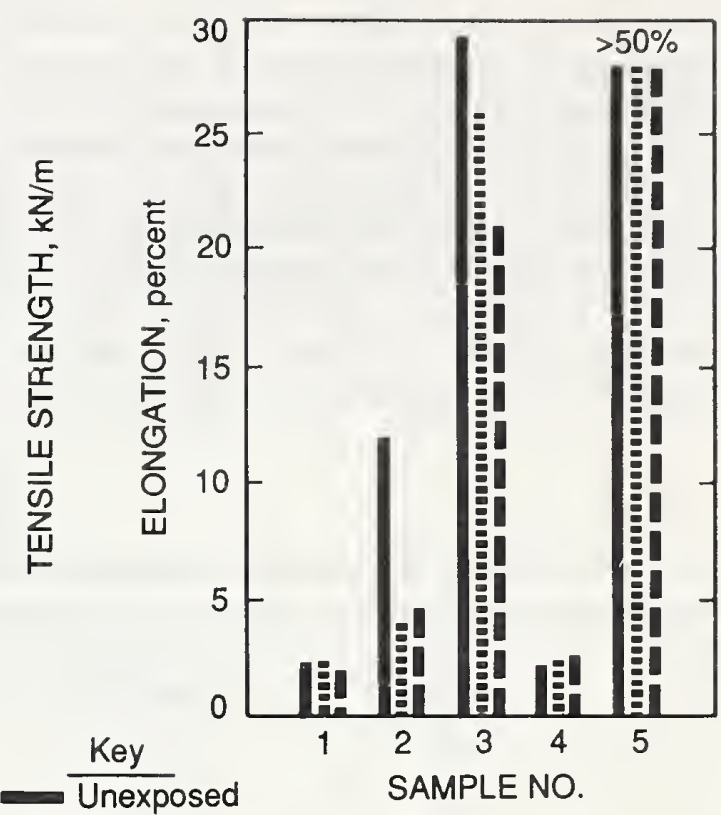

Figure A2. Elongation results

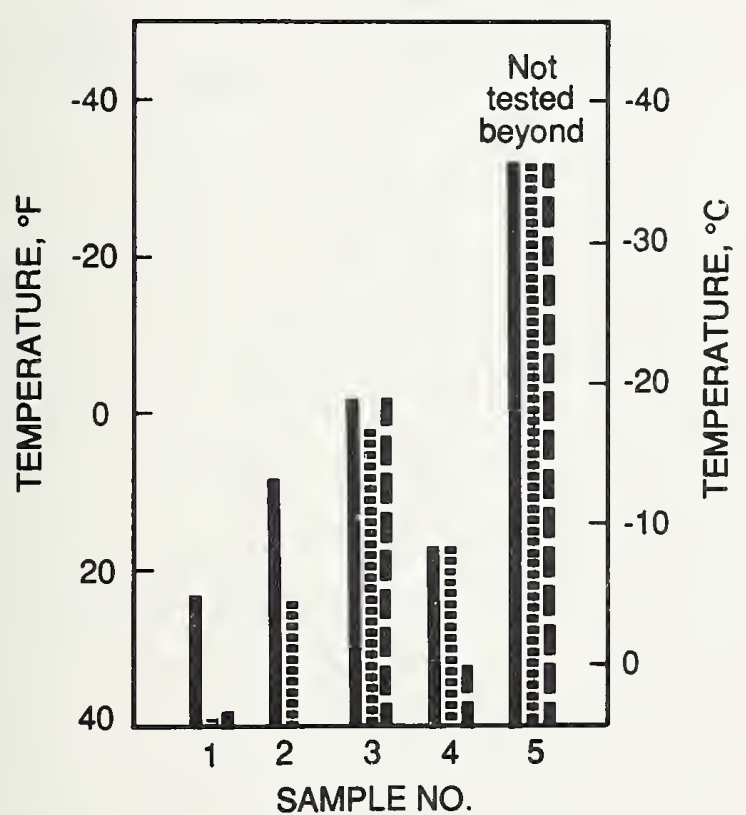

Figure A3. Low-temperature flexibility results

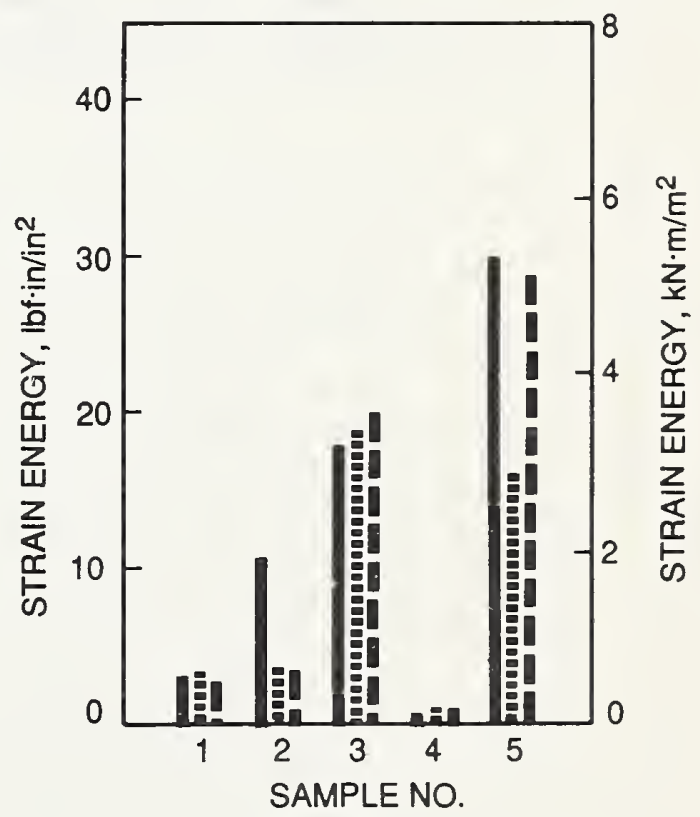

Figure A4. Strain energy results 
Table A14 gives a comparison of the results of membrane materials in the heat exposure test to the criteria for behavior upon heat exposure, as suggested in section 3.2.9. It is evident that only one of the five materials meet the suggested criteria, although Sample 4 had a strain energy less than 3 $\mathrm{lbf} \cdot \mathrm{in} / \mathrm{in}^{2}\left(0.5 \mathrm{kN} \cdot \mathrm{m} / \mathrm{m}^{2}\right)$ before heat exposure. Nevertheless, this observation is not considered a limitation to use of the proposed criteria on an interim preliminary basis. The criteria have been taken from existing documents (consistent with the objective of the study) which have achieved acceptance by the roofing industry in the area of the world where they were developed. The criteria for tensile strength and elongation were proposed by the MRCA [16]. The criterion for low-temperature flexibility was promulgated by the European Board of Agrement [14,15].

No criteria were suggested for the UV exposure tests. The ASTM draft suggests that load, elongation, low-temperature flexibility, and strain energy be measured before and after exposure [18]. However, data relating the suggested ASTM UV test procedure to resistance to exposure to solar radiation have not been developed. In general, experience with UV testing of modified bitumens has been limited, and a basis does not exist on which to suggest criteria. Research is needed to fill this gap and develop the basis for suggesting UV exposure criteria.

Table A14. Test results of the heat-exposed samples compared with the suggested criteria

\begin{tabular}{ccccc}
\hline \hline $\begin{array}{c}\text { Sample } \\
\text { No. }\end{array}$ & \multicolumn{4}{c}{ Conformance to the Suggested Criterion } \\
\cline { 2 - 5 } & Tensile & Elongation & Low-Tempo Fler & Strain Energy \\
\hline 1. & Yes & Yes & No & Yes \\
2. & Yes & No & Yes & Yes \\
3. & Yes & Yes & Yes & Yes \\
4. & Yes & Yes & Yes & No \\
5. & No & NA & Yes & Yes \\
\hline
\end{tabular}




\section{APPENDIX B. ASTM DRAFT TEST PROCEDURES CITED IN THE CRITERIA}

This appendix reproduces the ASTM draft test procedures for modified bitumens that are cited in the main text of the report (table 7). The procedures are reproduced with the permission of the Chairman of ASTM Committee D08. As the present report was nearing completion, the ASTM draft procedures had been thoroughly debated by Subcommittee D08.04, and were close to acceptance in a ballot of April 1988. Although it is anticipated that they will eventually be approved by ASTM D08 without major changes, the reader is cautioned to check with D08 for the latest version of the list of procedures. 
PROPOSED STANDARD TEST METHODS FOR SAMPLING AND TESTING MODIFIED BITUMINOUS SHEET MATERIALS USED IN ROOFING AND WATERPROOF ING

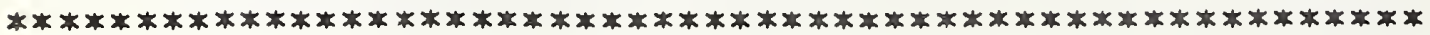

.D 0000

1. Scope

1.1 These test methods cover procedures for sampling and testing prefabricated, reinforced, polymer modified bituminous sheet materials designed for single or multiple ply application. in roofing and waterproofing membranes. These products consist of a core material covered on either one or both sides with polymer modified bitumen. These products may employ various surfacing materials on one side.

1.2 This standard may involve hazardous materials, operations, and equipment. This standard does not purport to address all of the safety aspects associated with its use. It is the responsibility of whoever uses this standard to consult and establish appropriate safety and health practices and determine the applicability of regulatory limitations prior to use.

1.3 These methods appear in the following order.

Section

Sampling

Conditioning

Thickness

Load Strain Properties

Tear Resistance

Moisture Content

Water Absorption

Dimensional Stability

Low Temperature Flexibility

Heat conditioning

Accelerated Weathering

Granule Embedment 
2. Referenced Documents

\subsection{ASTM Standards}

D 95 Standard Test Method for Water in Petroleum Products and Bituminous Materials by Distillation

D 146 Standard Methods of Sampling and Testing Bitumen-Saturated Felts and Woven Fabrics for Roofing and Waterproofing

D 573 Standard Test Method of Rubber Deterioration in an Air Oven

D 751 Testing Coated Fabrics

D 1079 Standard Definitions of Terms Relating to Roofing, Waterproofing, and Bituminous Materials

D 1204 Test Method for Linear Dimensional Changes of Nonrigid Thermoplastic Sheeting at Elevated Temperature

D 2523 Recommended Practice for Testing Load-Strain Properties of Roofing Membranes

D 2565 Xenon Arc Type (Water Cooled) Light Exposure Apparatus with and Without Water for Exposure of Plastics

D 4073 Standard Test Method for Tensile-Tear Strength of Bituminous Roofing Membranes

3. Sampling

3.1 From each shipment or fraction thereof select at random a number of rolis equal to one half the cube root of the total number of rolls in the lot. If the calculated number is fractional, express it as the next highest whole number. For convenience, a table, showing the number of rolls to be selected from lots of various sizes, is given in ASTM standard D 146. When mutualiy agreed upon by the concerned parties, other sampling frequencies may be used and reported within the framework of these procedures. The minimum sample shall consist of five rolls. The rolls so selected constitute the representative sample used for all 
subsequent observations and tests pertaining to the lct of material being examined.

4. Conditioning

4.1 Unless otherwise specified, condition test specimens for 4 hours at $73 \pm 4^{\circ} \mathrm{F}\left(23 \pm 3^{\circ} \mathrm{C}\right)$ and $50 \pm 5 \%$ relative humidity prior to testing.

5. Thickness. ASTM D 751

5.1 Sheet materials shail be checked at five points across the roll width, to include the weathering surface. Measurements shall be made at two points each being a minimum of six inches from each edge, and at three points equally spaced between these two points. Compute the average thickness and the standard deviation of the thicknesses based on the total number of of point measurements from all of the rolls taken in accordance with section 3 .

5.2 Report the individual point measurements, average, and estimated standard deviation.

6. Load-strain Properties

This method covers the determination of the load-strain (tensile-elongation, and strain energy) properties of polymer modified bituminous sheets, as set forth in ASTM D 2523 except as noted below.

\section{1 Specimens}

6.1.1 Prepare five specimens from each sample roll in both the longitudinal and transverse directions for each temperature to be tested. Specimens shall be $1.0 \mathrm{in}$ ( $25 \mathrm{~mm}$ ) wide by a minimum of $6.0 \mathrm{in}(150 \mathrm{~mm})$ long for sheet materials having an ultimate elongation of $75 \%$ or less at $0^{\circ} \mathrm{F}\left(-18^{\circ} \mathrm{C}\right)$. Specimens shall be 0.5 in $(12.5 \mathrm{~mm})$ wide by a minimum of 4.0 in $(100 \mathrm{~mm})$ long for materials having an ultimate elongation of greater than $75 \%$ at $0^{\circ} \mathrm{F}\left(-18^{\circ} \mathrm{C}\right)$.

\subsection{Procedure}

6.2 .1 Condition each specimen at least 2 hours at the selected test temperature.

$4^{\circ} \mathrm{F}\left(-18 \pm 3^{\circ} \mathrm{C}\right)^{2}$.

6.2 .3 Use a constant rate of elongation (CRE) tension testing machine, preferably with automatic load 
and strain recording equipment, and clamps that permit a uniform clamping pressure on the specimen without sipping. The initial clamp separation shall be minimum of $3.0 \pm 0: 125$ in $(75 \pm 2 \mathrm{~mm})$ for sheet materials having an ultimate elongation of $75 \%$ or less at $0^{\circ} \mathrm{F}\left(-18^{\circ} \mathrm{C}\right)$, and $2.0 \pm 0.125$ in $(50 \pm 2 \mathrm{~mm})$ for sheet materials having an ultimate elongation greater than $75 \%$ at $0^{\circ} \mathrm{F}\left(-18^{\circ} \mathrm{C}\right)$.

6.2 .4 Maintain a rate of separation of $2.0 \mathrm{in} / \mathrm{min} \pm$ $3 \%(50 \mathrm{~mm} / \mathrm{min} \pm 3 \%)$ for specimens tested at $73 \pm 4^{\circ} \mathrm{F}$ and a rate of separation of $0.8 \mathrm{in} / \mathrm{min} \pm 3 \%(2.0 \mathrm{~mm} / \mathrm{min} \pm 3 \%)$ for specimens tested at $0 \pm 3^{\circ} \mathrm{F}$.

\subsubsection{Record the percent elongation of each} specimen at specimen break and also at maximum load using an extensiometer, or calculate the percent elongation at specimen break and also at maximum load from the chart of the stress versus time knowing the speed of the chart drive and the jaw separation rate. each specimen.

6.2.6 Record the breaking load and maximum load of

\subsection{Calculation}

6.3.1 Determine the percent elongation at break obtained from the extensiometer in accordance with the manufacturer's instructions, or read directly. Calculate the percent elongation determined from the chart, without an extensiometer, as follows:

$$
\begin{aligned}
\text { Percent elongation }=\frac{a-b}{b} \times 100 \text { at break. } \\
a=\text { jaw separation at specimen break } \\
=\frac{\text { max. ext. on chart } \times \text { jaw separation rate }}{\text { chart speeo }} \\
b=\text { initial jaw separation }
\end{aligned}
$$

6.3.2 Determine the average percent elongation at break in each direction and the standard deviation of percent elongation at break in each direction based on the total number of measurements taken.

6.3.3 Calculate the percent elongation at maximum load obtained from the extensiometer in accordance with the manufacturer's instructions, or read directiy. Calculate the strain at maximum load determined from the chart, without an extensiometer, as follows:

$$
\begin{aligned}
\text { Percent elongation }=\frac{c-b}{b} \times 100 \text { at maximum load. } \\
c=\text { jaw separation at maximum load } \\
=\frac{\text { max. ext. on chart } \times \text { jaw separation rate }}{\text { chart speed }}
\end{aligned}
$$


6.3.4 Calculate the average percent elongation at maximum load in each direction and the standard deviation of percent elongation at maximum load in each direction based on the total number of measurements taken.

6.3.5 Calculate the average breaking load in each direction and the standard deviation of the breaking loads in each direction based on the total number of measurements taken.

6.3.6 Calculate the average maximum load in each direction and the standard deviation of the maximum loads in each direction based on the total number of measurements taken.

\subsubsection{Calculate the strain energy as the area} under the load-elongation (tensile-elongation) curve as obtained from the machine chart or computer system, and converted to units of $7 \mathrm{bfin/in}(\mathrm{kNM} / \mathrm{M})$.

6.3 .8 Calculate the average strain energy at maximum load and break in each direction and the standard deviation of the strain energies in each direction based on the total number of measurements taken.

\subsection{Report}

6.4.1 For each set of five specimens in each direction, record the temperature of the test, specimen size, individual measurements, average, and estimated stardard deviation of the maximum load in lof/in (Newtons), the breaking load in lbf/in (Newtons), the percent elongation at break, the percent elongation at maximum load, method of determining elongation, and the strain energy in in ibfin/in $(\mathrm{kNM} / \mathrm{M})$ at maximum load and break.

\section{Tear strength}

This method determines the tensile-tear strength of polymer modified bituminous sheets.

7.1 Prepare "five specimens from each sample roll in accordance with ASTM D 4073. Condition specimens as set forth in section 4 .

7.2 Test procedure shall be in accordance with ASTM D 4073, exCEDt that the rate of jaw separation shall be $2.0 \mathrm{in} / \mathrm{min} \pm 3 \%(50 \mathrm{~mm} / \mathrm{min} \pm 3 \%)$ for testing at $73 \pm 4^{\circ} \mathrm{F}$.

7.3 Calculate the average tear strength in each direction and the standard deviation of the tear strength in 
each direction based on the total number of measurements taken.

7.4 Report the individual specimen values, average, and estimated standard deviation of the specimens in each direction.

8. Moisture Content

This method determines moisture content in polymer modified bituminous sheets.

8.1 Prepare five specimens measuring approximately 4 in $X$ in $(100 \mathrm{~mm} \times 100 \mathrm{~mm})$ from each sample roll.

8.2 Determine the mass of each specimen to the nearest $0.1 \mathrm{gram}$. Determine the moisture content in accordance with ASTM D 95. Express water as a percent of dry mass.

8.3 Calculate the average moisture content and the standard deviation of the moisture contents based on the total number of measurements taken.

8.4 Report the individual specimen values, average, and estimated standard deviation.

9. Water Absorption

This method determines water absorption of polymer modified bituminous sheets.

9.1 Prepare five specimens measuring approximately 4 ir. $x$ in (100mm $x 100 \mathrm{~mm}$ ) from each sample roll. Seal all cut edges having exposed reinforcement with hot bitumen prior to testing.

9.2 Immerse the specimens in a distilled water bath maintained at $122 \pm 4^{\circ} \mathrm{F}\left(50 \pm 2^{\circ} \mathrm{C}\right)$ for $100 \pm 4$ hours, remove the specimens, blot off surface water with a dry cloth, immerse the specimens in technical grade acetone for 2:! seconds. and permit to air dry in laboratory for $15 \pm 2$ minutes at $73^{+} 4^{\circ} \mathrm{F}$ $\left(23 \pm 2^{\circ} \mathrm{C}\right)$ and $50 \pm 5 \% \mathrm{RH}$.

9.3 Determine the mass of each specimen to the nearest 0.1 gram after immersion. Determine moisture content in accordance with ASTM D 95. Express water as a percent of dry mass.

9.4 Determine the total percent of moisture gained by subtracting the moisture content as obtained in section 8 from the moisture content after immersion as determined in this section. 
9.5 Calculate the average percent of moisture gain and the standard deviation of cercent of moisture gains based on the total number of measurements taken.

9.6 Report the individual specimen values, average, and estimated standard deviation.

10. Dimensional Stability

This method determines dimensional stability of polymer modified bituminous sheets in accordance with ASTM D 1204 , except as noted below.

10.1 Prepare five specimens from each sample roll: one specimen from each edge of the sheet and three randomly across the sheet.

10.2 Condition the specimens in an oven maintained at $176 \pm 4^{\circ} \mathrm{F}\left(80 \pm 2^{\circ} \mathrm{C}\right)$ for 24 hours \pm 15 minutes.

10.3 After oven conditioning, cool the specimens and measure as indicated in ASTM D 1204.

10.4 Calculate the absolute dimensional change based on the absolute difference between the initial measurements and the measurement after conditioning for each specimen.

10.5 Calculate the average absolute dimensional change in each direction and the standard deviation of the absolute dimensional changes in each direction based on the individual results calculated in section 10.5 .

10.6 Report the initial measurements of the individual specimens, measurements of individual specimens after conditioning, dimensional change in each direction for each specimen, absolute dimensional change in each direction for each specimen, absolute average, and estimated standard deviation in each direction.

11. Low Temperature Flexibility

This method determines the low temperature flexibility of polymer modified bituminous sheets.

11.1 Low temperature flexitility is defiried as the lowest temperature recorded at which no visual signs of cracking in the membrane are observed after bending $180 \pm 5^{\circ}$ at the desired temperature around a $1.00 \pm 0.05 \mathrm{in} .(25 \pm 2 \mathrm{~mm})$ mandrel in approximately 21 seconds.

11.2 Prepare five specimens from each sample roll in 
both the longitudinal and transverse direction for each temperature to be tested. Specimens shall be $1.0 \pm 0.05$ in. $(25 \pm 2 \mathrm{~mm})$ wide by $6.00 \pm 0.005 \mathrm{in.}(150 \pm 2 \mathrm{~mm})$ rong.

11.3 Begin testing at a temperature where the sheet is known to pass, allowing the refrigerated unit, mandrel, and specimens to equilibrate for a minimum of 2 hours, and decrease or increase temperature in $5 \pm 2^{\circ} \mathrm{F}\left(3 \pm 1^{\circ} \mathrm{C}\right)$ increments.

(NOTE: If this information is not readily available, make preliminary screening test at $10 \pm 2^{\circ} \mathrm{F}$ intervals.)

11.4 After the specimens have been conditioned. Position the center of the specimen firmly on the mandrel weathering side up and bend the projecting ends without exerting any stress other than that required to keep the specimen in contact with the mandrel. Complete the entire procedure inside the refrigerated unit.

11.4.1 Bend the specimen until the projecting ends of the specimen are paraliel to each other keeping the bottom surface in contact with the mandrel through an arc of $180 \pm 5^{\circ}$.

11.4.2 Remove the specimen from the refrigerated unit and visualiy inspect the specimens for any signs of cracking.

specimens.

11.4.3 Repeat the above for any remaining

11.4.4 If any cracking is observed, increase the temperature in the refrigerated unit by $5 \pm 2^{\circ} \mathrm{F}\left(3 \pm 1^{\circ} \mathrm{C}\right)$. If no cracking was evident, decrease the temperature by $5 \pm 2^{\circ} \mathrm{F}\left(3 \pm 1^{\circ}\right.$ c). Condition ten new specimens at the next test temperature for a minimum of 2 hours. If the specimens have been preconditioned and the temperature change is no greater than $5^{\circ}$ $F$, the specimens may be reconditioned for $30 \pm 5 \mathrm{~min}$ after the chamber reaches equitibrium.

11.5 Repeat section 11.3 until the lowest temperature at which none of the specimens show cracking is achieved.

11.6 Report the low temperature flexibility in

${ }^{\circ} F\left({ }^{\circ} \mathrm{C}\right)$ as the lowest temperature at which cracking does not occur.

12. Heat Conditioning

This method determines the effects of heat conditioning on polymer modified bituminous sheets.

12.1 Prepare five specimens from each sample roll in the longitudinal and transverse directions of necessary sizes for tensile, elongation, and low temperature flexibility 
testing before and after conditioning. Sufficient specimen should be conditioned to accommodate subsequent testing.

12.2 Condition specimens in a forced air oven at $158 \pm 5^{\circ}$ $F\left(70 \pm 3^{\circ} \mathrm{C}\right)$ for 900.25 days in accordance with ASTM D 573. Evaluate physical properties are before and after conditioning.

12.3 Report the individual specimen values, average, and estimated standard deviation for tensile, elongation, strain energy, and low temperature flexibility, as set forth in the methods for determination of these properties, before and after heat conditioning.

13. Accelerated Weathering

This method determines the effects of accelerated weathering on polymer modified bituminous sheets in accordance with section 7 of ASTM D 2565 except as noted below.

13.1 The irradiance shall be $0.35 \mathrm{~W} / \mathrm{M}$ at $340 \mathrm{nM}$ and a black body temperature of $140 \pm 5^{\circ} \mathrm{F} \quad\left(60 \pm 3{ }^{\circ} \mathrm{C}\right)$.

13.2 Use a cycle of 60 minutes with 51 minutes arc only and 9 minutes of arc and water spray per cycle. hours).

13.3 Expose the specimens for $83 \pm 0.35$ cycles $(2000 \pm 8$

13.4 Orient the intended weathering surface should be toward the light source.

13.5 Expose a sufficient quantity of specimens from each sample roll for tensile, elongation, and low temperature flexibility testing after accelerated weathering. Specimens shall be cut to size and quantity aiter weathering.

13.6 Report the individual specimen values, average, and estimated standard deviation for tensile, elongation, strain energy, and low temperature flexibility, as set forth in the methods for determination of these properties, before and after weathering.

14. Granule Embedment (For granule surfaced membranes only)

This method determines granule loss on mineral surfaced polymer modified bituminous sheets.

\subsection{Apparatus}

14.1.1 The granule adhesion testing machine is equipped with a test brush consisting of 22 bundles of steel 
bristles arranged in four rows alternately. The test machine will provide a stroke such that the total abraded area on the test specimen is approximately $1.38 \mathrm{in}$. $x 6.77 \mathrm{in}$. (35mm $x$ $172 \mathrm{~mm})$. $^{1}$

\subsection{Procedure.}

14.2.1 Attach the brush to the machine with the $25 \mathrm{~mm}$ ( $1 \mathrm{in}$ ) dimension of the brush parallel to the stroke ine. Adjust the mass of the brush plus its holder to 5.84 1b ( 2650 grams) so that the downward pressure exerted on the test specimen is equal to $4.01 \mathrm{bf} / \mathrm{in}$ ( $28 \mathrm{kPa})$.

\subsubsection{From each sample roll prepare five} specimens in the longitudinal direction with the following dimensions: $1.38 \pm 0.05 \mathrm{in} . \times 6.77 \pm 0.05 \mathrm{in} .(50 \pm 2 \mathrm{~mm} \times 229 \pm 2 \mathrm{~mm})$ and condition as specified in section 4 of this document.

\subsubsection{Test each specimen individually}

14.2.4 Tap each specimen to shake off any loose granules, determine the mass of the specimen to the nearest 0.1 gram.

14.2.5 Secure the specimen on the test machine with the granule surface facing the test brush.

14.2.6 subject the specimen to 50 double strokes of the brush, remove the specimen, tap to remove any loose granules, determine the mass of the specimen to the nearest 0.1 gram.

14.2.7 Calculate the mass loss in grams to the nearest 0.1 grams after 50 double strokes for each specimen. Average the five results for the final granule loss for each sample roll.

sample roll.

14.2.8 Report the average granule loss for each

\section{Compound Stability}

This method determines high temperature stability of polymer modified bituminous sheets.

\section{1 specimens}

15.1.1 From each sample roll prepare five specimens in both the longitudinal and transvarae directions for each test temperature. Specimens shall be $2.0 \pm 0.05 i n$. $(50 \pm 2 \mathrm{~mm})$ wide by $3.0 \pm 0.05 \mathrm{in}$. $(75 \pm 2 \mathrm{~mm}) 10 \mathrm{ng}$.

\subsection{Apparatus}


15.2.1 Bulldog type clamps with smooth surfaced clamping faces at least 2 inches wide are used to suspend the specimens in a forced air oven.

45.2.2 The forced air oven shall be capable of maintaining the preset test temperature to a tolerance of $\pm 5^{\circ} \mathrm{F}\left( \pm 3^{\circ} \mathrm{C}\right)$. Set the forcred air oven at $175 \pm 5^{\circ} \mathrm{F}\left(79.4 \pm 3^{\circ} \mathrm{C}\right)$, and allow the oven to equilibrate prior to testing.

\subsection{Procedure}

15.3.1 Clamp each specimen on the 2.0in. (50mm) edge with a buli dog clamp.

15.3.2 Suspend the specimen via the clamp in the forced air oven with the $3.0 \mathrm{in}$. $(75 \mathrm{~mm})$ edge of the specimen set vertically.

15.3.3 After the specimens have been conditioned for at least 2 hours 15 minutes at the specified temperature observe each specimen for signs of flowing, dripping, or drop formation on the lower edge of the specimen.

15.3.4 If flowing, dripping, or drop formation is not observed increase the oven temperature by $25 \pm 5 \mathrm{~F}$, allow the oven to equilibrate and repeat procedure 15.3. Maximum temperature shall not exceed $250: 5^{\circ} \mathrm{F}\left(121 \pm 3^{\circ} \mathrm{C}\right)$.

15.4 Report the test temperature at which flowing, dripping, or drop formation is observed. Provide descriptions of visible results and the number of specimens undergoing any change.

16. Precision and Bias

The precision and bias of these test methods as related to polymer modified bituminous sheets have not been established. Round Robin test will be conducted to establish these values.

1. As furnished by Minnesota Mining and Manufacturing Co. (3M) Incustrial Products Division, St. Paul Minneadolis, MN 55101. 


\section{APPENDIX C. UEATC TEST PROCEDURES CITED IN THE CRITERIA}

(table 7).

This appendix gives the two UEAtc [13] test procedures cited in the main text of the report

\section{C.1 Test for Sliding Resistance (Para. 5.1.7)}

Test only necessary for systems that are to be used on sloping roofs and is not necessary when mechanical fixing at the top of the roofing sheets is provided.

\section{Apparatus}

A source of radiant heat.

\section{Test Samples}

The material is bonded to a concrete slab $300 \times 300 \mathrm{~mm}$.

\section{Method}

The sample is inclined at the maximum intended slope and the entire surface of the specimen is maintained at $70^{\circ} \mathrm{C}$ for 7 days. Any movement is measured.

Note: For special climatic conditions, high temperatures of up to $80^{\circ} \mathrm{C}$ may be necessary.

\section{C.2 Unrolling Test at Low Temperature (Para. 5.4.3)}

\section{Apparatus}

Cold room at $0^{\circ} \mathrm{C}$.

Test Samples

A roll of the material as supplied by the manufacturer.

\section{Method}

The roll of waterproofing is stored at $0{ }^{\circ} \mathrm{C}$ for 24 hours; on removal from storage it is immediately unrolled in approxiately 15 seconds onto a flat surface. 

NBS.114A (REV. 2.8C)

U.S. DEPT. OF COMM.

BIBLIOGRAPHIC DATA

SHEET (See in structions)

4. TITLE AND SUBTITLE

1. PUBLICATION OR
REPORT NO.
NIST/BSS-167

2. Performing Organ. Report Nod

3. Publication Date

February 1989

Interim Criteria for Polymer-Modified Bituminous Roofing Membrane Materials

5. $A U T H O R(S)$

Walter J. Rossiter, Jr. and James F. Seiler, Jr.

6. PERFORMING ORGANIZATION (If joint or other than NBS, see instructions)

NATIONAL INSTITUTE OF STANDARDS AND TECHNOLOGY

(formerly NATIONAL BUREAU OF STANDARDS)

U.S. DEPARTMENT OF COMMERCE

GATHERSBURG, MD 20899

9. SPONSORHN ORGANHZATION NAME AHD COMPLETE ADDRESS (Street, City, StOTE, ZIP)

7. ContracVGrant No.

8. Type of Report \& Perlod Covered

Final

Tri-Service Building Materials Committee

10. SUPPLEMENTARY NOTES

Document describes a computer program; SF-185, FIPS Software Summary, is attached.

11. ABSTRACT (A 200-word or less factual summary of most significant information. If document includes a significant bibliography or literature survey. mention it here)

This report presents the results of a study to develop interim criteria for the selection of polymer-modified bituminous roofing membrane materials. The criteria are based on a review of existing standard specifications and related documents. They are intended for use by the construction agencies of the Department of Defense in specifying polymer-modified bituminous roofing membrane materials until voluntary consensus standards are developed in the United States.

The suggested interim criteria are generally presented using a performance criteria format. The membrane characteristics for which performance criteria are suggested are: dimensional stability, fire, flow resistance, hail impact, moisture content and absorption, pliability, strain energy, uplift resistance, and weathering resistance (heat exposure). Prescriptive criteria for five membrane characteristics are used to complement the suggested performance criteria. The approach of using complementary prescriptive criteria is taken to incorporate in the performance criteria tests methods which can be relatively rapidly performed for characterization or identification of the membrane material.

Other membrane requirements are listed for future development of criteria, but performance criteria for these requirements are not suggested at the present. Lack of a consistent database in the existing standards and related documents precludes suggesting criteria at this time. It is considered beneficial to present the needed criteria as a first step toward directing future research for standards development for polymer-modified bituminous roofing membrane materials.

12. KEY WORDS (Six to twelve entries: alphabetical order; capitalize only proper names; and separate key words by semicolons)

characteristics; membranes; low-sloped roofing; performance criteria; prescriptive criteria; polymer-modified bitumens; properties; roofs; test methods

13. AVAILABILITY

X] Unlimited

$\square$ For Official Distribution. Do Not Release to NTIS

[X] Order From Superintendent of Documents, U.S. Government Printing Office, Washington, D.C. 20402.

14. NO. OF

PRINTED PAGES

Order From National Technical Information Service (NTIS), Springfield, VA. 22161

50

15. Price 




\section{Technical Publications}

\section{Periodical}

Journal of Research of the National Institute of Standards and Technology-Reports NIST research and development in those disciplines of the physical and engineering sciences in which the Institute is active. These include physics, chemistry, engineering, mathematics, and computer sciences. Papers cover a broad range of subjects, with major emphasis on measurement methodology and the basic technology underlying standardization. Also included from time to time are survey articles on topics closely related to the Institute's technical and scientific programs. Issued six times a year.

\section{Nonperiodicals}

Monographs-Major contributions to the technical literature on various subjects related to the Institute's scientific and technical activities.

Handbooks-Recommended codes of engineering and industrial practice (including safety codes) developed in cooperation with interested industries, professional organizations, and regulatory bodies. Special Publications-Include proceedings of conferences sponsored by NIST, NIST annual reports, and other special publications appropriate to this grouping such as wall charts, pocket cards, and bibliographies.

Applied Mathematics Series-Mathematical tables, manuals, and studies of special interest to physicists, engineers, chemists, biologists, mathematicians, computer programmers, and others engaged in scientific and technical work.

National Standard Reference Data Series-Provides quantitative data on the physical and chemical properties of materials, compiled from the world's literature and critically evaluated. Developed under a worldwide program coordinated by NIST under the authority of the National Standard Data Act (Public Law 90-396). NOTE: The Journal of Physical and Chemical Reference Data (JPCRD) is published quarterly for NIST by the American Chemical Society (ACS) and the American Institute of Physics (AIP). Subscriptions, reprints, and supplements are available from ACS, 1155 Sixteenth St., NW., Washington, DC 20056.

Building Science Series-Disseminates technical information developed at the Institute on building materials, components, systems, and whole structures. The series presents research results, test methods, and performance criteria related to the structural and environmental functions and the durability and safety characteristics of building elements and systems.

Technical Notes-Studies or reports which are complete in themselves but restrictive in their treatment of a subject. Analogous to monographs but not so comprehensive in scope or definitive in treatment of the subject area. Often serve as a vehicle for final reports of work performed at NIST under the sponsorship of other government agencies.

Voluntary Product Standards-Developed under procedures published by the Department of Commerce in Part 10, Title 15, of the Code of Federal Regulations. The standards establish nationally recognized requirements for products, and provide all concerned interests with a basis for common understanding of the characteristics of the products. NIST administers this program as a supplement to the activities of the private sector standardizing organizations.

Consumer Information Series-Practical information, based on NIST research and experience, covering areas of interest to the consumer. Easily understandable language and illustrations provide useful background knowledge for shopping in today's technological marketplace.

Order the above NIST publications from: Superintendent of Documents, Government Printing Office, Washington, DC 20402.

Order the following NIST publications-FIPS and NISTIRs-from the National Technical Information Service, Springfield, VA 22161.

Federal Information Processing Standards Publications (FIPS PUB)-Publications in this series collectively constitute the Federal Information Processing Standards Register. The Register serves as the official source of information in the Federal Government regarding standards issued by NIST pursuant to the Federal Property and Administrative Services Act of 1949 as amended, Public Law 89-306 (79 Stat. 1127), and as implemented by Executive Order 11717 (38 FR 12315, dated May 11, 1973) and Part 6 of Title 15 CFR (Code of Federal Regulations).

NIST Interagency Reports (NISTIR)-A special series of interim or final reports on work performed by NIST for outside sponsors (both government and non-government). In general, initial distribution is handled by the sponsor; public distribution is by the National Technical Information Service, Springfield, VA 22161, in paper copy or microfiche form. 
U.S. Department of Commerce

National Institute of Standards and Technology

(formerly National Bureau of Standards)

Gaithersburg, MD 20899

\section{Official Business}

Penalty for Private Use $\$ 300$ 